\title{
Cholinergic Axons Modulate GABAergic Signaling among Hippocampal Interneurons via Postsynaptic $\alpha 7$ Nicotinic Receptors
}

\author{
Nicolas Wanaverbecq, ${ }^{1,2}$ Alexey Semyanov, ${ }^{1}$ Ivan Pavlov, ${ }^{1}$ Matthew C. Walker, ${ }^{1}$ and Dimitri M. Kullmann ${ }^{1}$ \\ ${ }^{1}$ Institute of Neurology, University College London, London WC1N 3BG, United Kingdom, and 2Biozentrum, University of Basel, CH-4056 Basel, \\ Switzerland
}

\begin{abstract}
Homopentameric $\alpha 7$ nicotinic receptors have a high affinity for acetylcholine (ACh), are permeable to $\mathrm{Ca}^{2+}$ ions, and are abundant in hippocampal interneurons. Although nicotinic agonists evoke inward currents and $\mathrm{Ca}^{2+}$ transients in stratum radiatum interneurons, the role of endogenous ACh in modulating synaptic integration by interneurons is incompletely understood. Many cholinergic axonal varicosities do not have postsynaptic specializations, but $\alpha 7$ receptors frequently occur close to synaptic $\mathrm{GABA}_{\mathrm{A}}$ receptors. These observations raise the possibility that $\alpha 7$ nicotinic receptors activated by ACh released from cholinergic axons modulate GABAergic transmission in interneurons. We show that agonists of $\alpha 7$ receptors profoundly depress GABAergic IPSCs recorded in stratum radiatum interneurons in the CA1 region of the hippocampus. This depression is accompanied by a small increase in GABA release. $\alpha 7$ nicotinic receptor agonists also depress GABA- or muscimol-evoked currents in interneurons, indicating that the major effect is a postsynaptic modulation of $\mathrm{GABA}_{\mathrm{A}}$ receptors. The depression of GABA-evoked currents is abolished by chelating $\mathrm{Ca}^{2+}$ in the recorded interneuron and attenuated by inhibitors of PKC. We also show that stimuli designed to release endogenous ACh from cholinergic axons evoke an $\alpha 7$ receptor-dependent heterosynaptic depression of GABAergic IPSCs in interneurons. This heterosynaptic modulation is amplified by blocking cholinesterases. These results reveal a novel mechanism by which cholinergic neurons modulate information processing in the hippocampus.
\end{abstract}

Key words: nicotinic; $\mathrm{GABA}_{\mathrm{A}}$ receptor; interneurons; cholinergic; hippocampus; inhibition

\section{Introduction}

The cholinergic innervation of the hippocampus from the medial septal nucleus/diagonal band complex (Mesulam, 2004a,b) plays an important role in rhythmogenesis (Lee et al., 1994) and is implicated in a variety of cognitive processes. Degeneration of cholinergic afferents contributes to memory impairment in Alzheimer's disease (Davies and Maloney, 1976; Mesulam, 2004a), and cholinesterase inhibitors are among the only treatments available (Cummings, 2004; Hogan et al., 2004).

$\mathrm{ACh}$ acts on metabotropic muscarinic receptors and ionotropic nicotinic receptors (nAChRs). Activation of nAChRs has been shown to improve performance in certain cognitive tasks (Newhouse et al., 2004). Homopentameric $\alpha 7$ nAChRs are an abundant subtype in the brain (Couturier et al., 1990), have a high $\mathrm{Ca}^{2+}$ permeability, and exhibit rapid desensitization (Ber-

Received Sept. 19, 2006; accepted April 18, 2007.

This work was supported by the Medical Research Council. We are indebted to R. L. Papke for the gift of $40 \mathrm{H}-$ GTS21, to R. Fabian-Fine, R. L. Papke, and C. J. Frazier for early discussions on the project, and to D. A. Rusakov and members of the laboratory for comments on this manuscript. Some experiments were performed at the Biozentrum, and we are very grateful to $A$. Lüthi for providing the experimental facilities. We are also grateful to P. H. Kullmann for help implementing the dynamic current-clamp method.

Correspondence should be addressed to Dimitri M. Kullmann, Institute of Neurology, Queen Square, London WC1N 3BG, UK. E-mail: d.kullmann@ion.ucl.ac.uk.

A. Semyanov's present address: RIKEN Brain Science Institute, Saitama, 351-0198, Japan.

D0I:10.1523/JNEUROSCI.1732-07.2007

Copyright $\odot 2007$ Society for Neuroscience $\quad$ 0270-6474/07/275683-11\$15.00/0 trand et al., 1993; Seguela et al., 1993; Hogg et al., 2003). They are densely expressed in the hippocampus, especially in interneurons (Freedman et al., 1993). Their number has been shown to decrease in schizophrenia (Freedman et al., 1995), and a polymorphism in the gene encoding $\alpha 7$ has been linked to a processing deficit associated with this disease (Freedman et al., 1997). $\alpha 7$ nAChRs have attracted considerable attention as a potential target in the treatment of schizophrenia and dementia (Ripoll et al., 2004).

Although the available anatomical data must be interpreted with caution (Herber et al., 2004), the expression of $\alpha 7 \mathrm{nAChRs} \mathrm{is}$ consistent with the finding that exogenous agonists directly excite interneurons, especially in stratum radiatum (Alkondon et al., 1997a; Jones and Yakel, 1997; McQuiston and Madison, 1999; Ji and Dani, 2000; Buhler and Dunwiddie, 2002). Exogenous nicotinic receptor agonists also evoke local $\mathrm{Ca}^{2+}$ transients in the dendrites of interneurons, consistent with the high $\mathrm{Ca}^{2+}$ permeability of $\alpha 7 \mathrm{nAChRs}$ (Khiroug et al., 2003; Vizi et al., 2004). How endogenous $\mathrm{ACh}$ released from cholinergic fibers acts on interneurons is less clear, but electrical stimuli have been reported to evoke synaptic currents mediated by nAChRs (Alkondon et al., 1998; Frazier et al., 1998b).

Anatomical studies have shown that nAChRs frequently occur at GABAergic synapses, both presynaptically and postsynaptically (Fabian-Fine et al., 2001; Kawai et al., 2002; Zago et al., 
2006). At ultrastructural resolution, postsynaptic $\alpha 7 \mathrm{nAChRs}$ have been reported both within the synapse and in a perisynaptic annulus, implying an intimate relationship with postsynaptic $\mathrm{GABA}_{\mathrm{A}}$ receptors (Fabian-Fine et al., 2001). $\alpha 7$ nAChRs, however, tend to occur relatively far from the sites of ACh release: most varicosities on cholinergic axons in the hippocampus are nonsynaptic (Umbriaco et al., 1995). This anatomical arrangement suggests that ACh carries a diffuse signal in the hippocampus (Descarries et al., 2004) that might modulate inhibitory neurotransmission among interneurons. Exogenous $\alpha 7 \mathrm{nAChR}$ agonists enhance transmitter release at various synapses (Seguela et al., 1993; McGehee et al., 1995; Gray et al., 1996; Alkondon et al., 1997a; MacDermott et al., 1999). However, little is known about postsynaptic effects of $\alpha 7 \mathrm{nAChRs}$ at GABAergic synapses.

We report here that $\alpha 7$ receptor activation by either exogenous agonists or endogenous $\mathrm{ACh}$ release inhibits $\mathrm{GABA}_{\mathrm{A}}$ receptor-mediated currents in hippocampal interneurons. These results point to a novel candidate mechanism by which the cholinergic innervation of the hippocampus exerts its cognitionmodulating effects.

\section{Materials and Methods}

Four-week-old male guinea pigs or 8-week-old male Sprague Dawley rats were killed in accordance with the United Kingdom Animals (Scientific Procedures) Act of 1986. Horizontal hippocampal slices (300-350 $\mu \mathrm{m}$ thick) were cut on a vibrating tissue slicer (VT1000S; Leica, Wetzlar, Germany) in an ice-cold oxygenated sucrose-based solution containing (in mM) 75 sucrose, $70 \mathrm{NaCl}, 2 \mathrm{KCl}, 1 \mathrm{NaH}_{2} \mathrm{PO}_{4}, 26.2 \mathrm{NaHCO}_{3}, 5.6$ $\mathrm{MgCl}_{2}, 0.5 \mathrm{CaCl}_{2}$, and 25 glucose, equilibrated with $95 \% \mathrm{O}_{2} / 5 \% \mathrm{CO}_{2}, \mathrm{pH}$ 7.4, adjusted to $315 \mathrm{mOsm}$. After recovering in an interface storage chamber in a sucrose-free solution, they were placed on a perfusion stage mounted on an upright microscope equipped with infrared differential interference contrast imaging. The perfusion medium contained (in $\mathrm{mM}$ ) $119 \mathrm{NaCl}, 2.5 \mathrm{KCl}, 1.3 \mathrm{MgCl}_{2}, 2 \mathrm{CaCl}_{2}, 26.2 \mathrm{NaHCO}_{3}, 1 \mathrm{NaH}_{2} \mathrm{PO}_{4}$, and 22 glucose and was equilibrated with $95 \% \mathrm{O}_{2} / 5 \% \mathrm{CO}_{2}$, $\mathrm{pH} 7.4$.

$\mathrm{CA} 1$ pyramidal cells or stratum radiatum interneurons were recorded in whole-cell voltage clamp using pipettes filled with a solution containing (in mM) $120 \mathrm{CsCl}, 10$ HEPES, 2 EGTA or 10 1,2-bis(2aminophenoxy)ethane- $N, N, N^{\prime}, N^{\prime}$-tetraacetic acid (BAPTA), $8 \mathrm{NaCl}$, $0.2 \mathrm{MgCl}_{2}, 2 \mathrm{Mg}$-ATP, $0.3 \mathrm{Na}_{3}$-GTP, and 5 5-N-(2,6-dimethylphenylcarbamoylmethyl)triethylammonium bromide (QX-314 Br), pH 7.2, $290 \mathrm{mOsm}$. The pipette resistance was 3-4 M $\Omega$. For perforated-patch recordings, $8 \mathrm{M} \Omega$ electrodes were used and filled with the above intracellular solution (with EGTA), to which amphotericin B was added (final concentration $75-150 \mu \mathrm{g} / \mathrm{ml}$ prepared from a stock in DMSO). The electrode tip was dip filled with an amphotericin-free solution for 15-30 $s$ and subsequently backfilled with the amphotericin-containing intracellular solution. QX-314 Br was present in the intracellular solution, and depolarizing voltage steps were intermittently delivered to evoke action currents to verify that the patch was not accidentally ruptured. The series resistance $(<15 \mathrm{M} \Omega$ and $<100 \mathrm{M} \Omega$ in whole-cell and perforated-patch configurations, respectively) was monitored throughout the experiment using a $-5 \mathrm{mV}$ step command, and cells showing unstable series resistance ( $>15 \%$ change) were rejected.

Cells were recorded at $23-25^{\circ} \mathrm{C}$ in voltage-clamp mode at a holding potential of $-60 \mathrm{mV}$ using an Axopatch 1D amplifier (Molecular Devices, Sunnyvale, CA). Evoked currents (inward currents with a $\mathrm{Cl}^{-}$ reversal potential of $\sim 0 \mathrm{mV}$ ) were low-pass filtered $(2 \mathrm{kHz})$ and acquired at $5 \mathrm{kHz}$ on a PC for off-line analysis [LabView (National Instruments, Austin, TX), MiniAnalysis (Synaptosoft, Decatur, GA), and Excel (Microsoft, Seattle, WA)]. Dynamic current clamp was implemented with G-clamp (Kullmann et al., 2004) running under LabView RealTime with an iteration frequency of $20 \mathrm{kHz}$.

To block fast glutamatergic transmission, NBQX (1,2,3,4-tetrahydro6-nitro-2,3-dioxo-benzo[f] quinoxaline-7-sulfonamide; $25 \mu \mathrm{M})$ and APV (DL-2-amino-5-phosphonopentanoic acid; $50 \mu \mathrm{M}$ ) were routinely added to the perfusion solution. $\mathrm{GABA}_{\mathrm{B}}$, group III metabotropic gluta- mate, muscarinic, $\alpha 4 \beta 2$ nicotinic, and $\mathrm{A}_{1}$ adenosine receptors were also blocked by adding to the perfusion medium CGP52432 (5 $\mu \mathrm{M})$, MSOP (RS- $\alpha$-methylserine-O-phosphate; $100 \mu \mathrm{M}$ ), atropine (1 $\mu \mathrm{M}), \mathrm{DH} \beta \mathrm{E}$ (dihydro- $\beta$-erythroidine; $1 \mu \mathrm{M}$ ) and DPCPX (8-cyclopentyl-1,3-dipropylxanthine; $200 \mathrm{nM}$ ), respectively.

IPSCs were evoked every $15 \mathrm{~s}$ with stimuli (100 $\mu \mathrm{s} ; 50-250 \mu \mathrm{A}$ square pulses) delivered via bipolar stainless steel electrodes (FHC, Bowdoinham, ME) positioned in stratum radiatum. Paired-pulse ratio (PPR) was measured as IPSC $\mathrm{IPSC}_{1}$ with an intertrial interval of $20 \mathrm{~ms}$. $\mathrm{GABA}_{\mathrm{A}}$ or $\mathrm{nAChR}$ agonists were pressure applied with a Picospritzer II (3-5 M $\Omega$ glass pipette; 5-50 ms at 15-20 psi; General Valve, Brookshire, TX). The agonists ( $100 \mu \mathrm{M}$ GABA, $10 \mu \mathrm{M}$ muscimol, $1 \mathrm{~mm}$ ACh, or $10 \mathrm{~mm}$ choline) were dissolved on the day of the experiments in artificial CSF containing the same mixture of antagonists present in the perfusion medium. For the experiments in Figure 2, 1\% dextran Texas Red 3000 molecular weight (MW) was included in the pipette solution to help visualize the main dendrites using a TILLVision imaging system (Till Photonics, Martinsried, Germany). A bipolar stimulating electrode, prepared from theta glass filled with extracellular medium, was used to evoke IPSCs, and a pressure-application pipette containing ACh was positioned near the visualized dendrite to activate nAChRs. For the heterosynaptic depression experiments, a second stimulus electrode was positioned in CA1 stratum radiatum or in the alveus/stratum oriens relatively far $(>1 \mathrm{~mm})$ from the recording site.

Where averages are shown, they represent all interneurons recorded. The data are shown normalized to baseline and expressed as mean \pm SEM. They were analyzed with nonparametric Wilcoxon paired or unpaired tests. Representative traces were averaged from 5-10 consecutive trials, and for the time-course plots, data points were binned in $30-45 \mathrm{~s}$ periods.

Chemicals were purchased from Sigma (St. Louis, MO). Receptor antagonists were purchased from Tocris Cookson (Bristol, UK) except staurosporine (Streptomyces sp.) and bisindolylmaleimide I (BisI; Merck, Darmstadt, Germany), FK506 (A.G. Scientific, San Diego, CA), the protein kinase C (PKC) inhibitory peptide (IP19-36; Alexis, Lausen, Switzerland) and dextran Texas Red 3000 MW (Invitrogen, Carlsbad, CA).

Bath perfusion of $10 \mathrm{~mm}$ ACh evoked an increase in holding current in stratum radiatum interneurons, consistent with activation of cationpermeable nAChRs (supplemental Fig. 1, available at www.jneurosci.org as supplemental material). Pilot experiments showed that local pressure application of $1 \mathrm{~mm}$ ACh in interneurons evoked similar inward currents in rat and guinea pig, which were blocked by $30 \mathrm{~nm}$ methyllycaconitine (MLA). Data shown in Figures 1, 2, 4B-E, 5, 6, and 7 and supplemental Figures 1, 3, 4, and 6 (available at www.jneurosci.org as supplemental material) were obtained from rat slices. Data in Figures 3, 4A, and 8 and supplemental Figures 2 and 5 (available at www.jneurosci.org as supplemental material) were obtained from guinea pig slices. The heterosynaptic depression phenomenon was demonstrated in slices from both species.

\section{Results}

\section{$\alpha 7$ nAChRs depress IPSCs}

Several studies have shown that excitatory actions of $\alpha 7 \mathrm{nAChR}$ agonists are prominent in interneurons in stratum radiatum (Frazier et al., 1998a; Ji and Dani, 2000; Khiroug et al., 2003), especially those close to stratum lacunosum-moleculare (McQuiston and Madison, 1999). We therefore focused attention on CA1 interneurons in this region, identified using infrared video microscopy (although we also present some data on pyramidal cells). To test whether the effects observed are species specific, we obtained data from rat and guinea pig. No differences were observed, and so data are presented together (see Materials and Methods for the species used for each illustrated experiment). To avoid potential contaminating polysynaptic effects, fast glutamatergic transmission was routinely blocked with selective antagonists, as were $\mathrm{GABA}_{\mathrm{B}}$, muscarinic, and nicotinic $\alpha 4 \beta 2$ receptors.

We evoked monosynaptic GABAergic IPSCs by delivering 
A ACh, $10 \mathrm{mM}$

D ACh, $0.3 \mathrm{mM}$
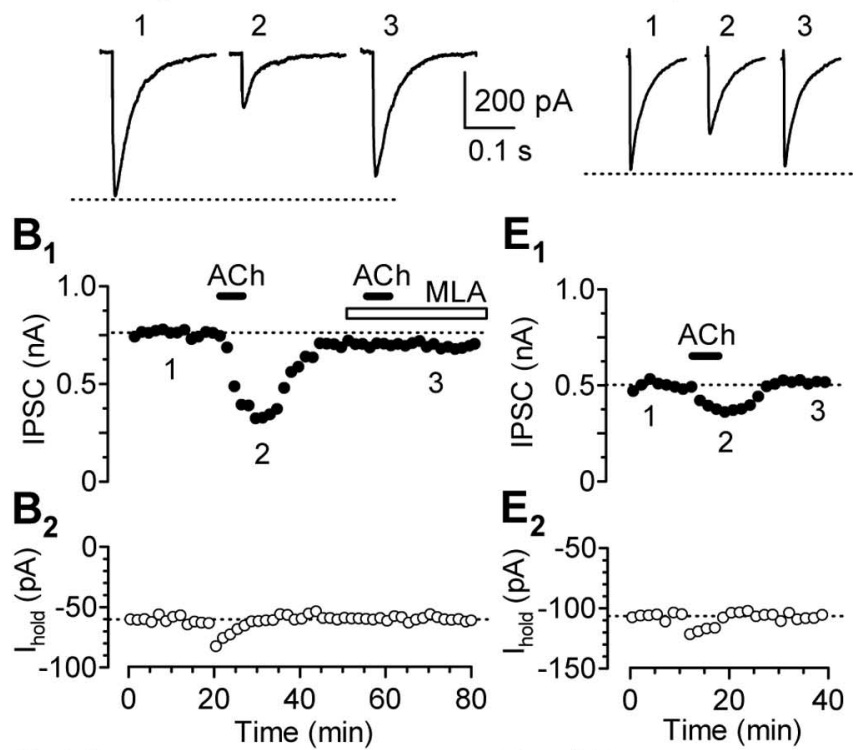

$E_{1}$

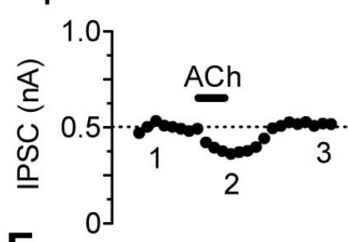

$\mathrm{E}_{2}$
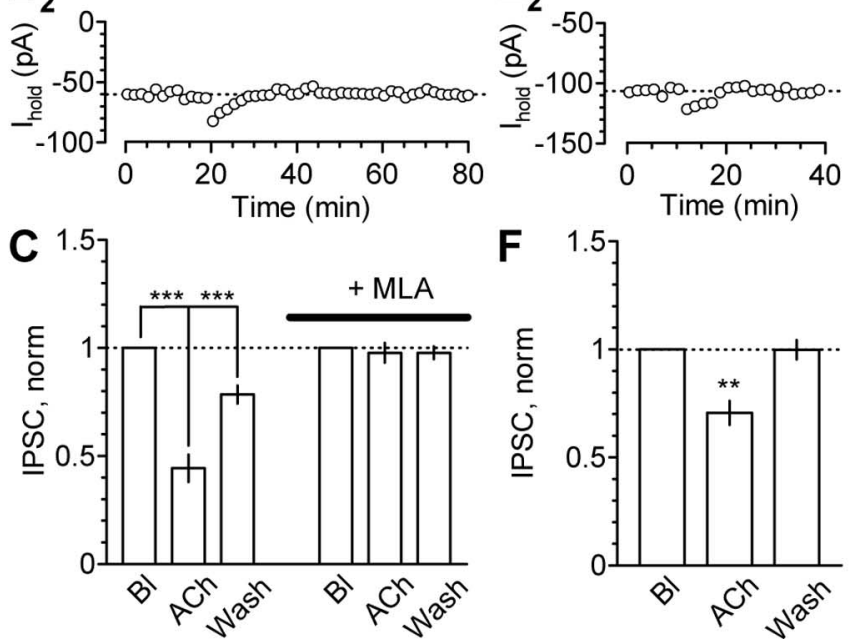

Figure 1. ACh depresses elPSCs in stratum radiatum interneurons. $A$, Representative elPSCS recorded from an interneuron in stratum radiatum during baseline (1), during bath application of $10 \mathrm{~mm} \mathrm{ACh} \mathrm{(2),} \mathrm{and} \mathrm{after} \mathrm{washout} \mathrm{in} \mathrm{the} \mathrm{presence} \mathrm{of} 100 \mathrm{~nm} \mathrm{MLA}$, an $\alpha 7 \mathrm{nAChR}$-selective antagonist (3). B1, Time course plots showing the effect of ACh on the elPSC amplitude (B1) and holding current (B2) and blockade of the effect by MLA (same cell as shown in $\boldsymbol{A}$ ). C, Summary of data obtained in five cells. ACh, After $10 \mathrm{~mm}$ ACh application; Wash, recovery after $10 \mathrm{~min}$ washout. The data obtained in the presence of MLA $(+M L A)$ were renormalized to a new baseline. $\boldsymbol{D}$, Representative elPSCs before (1), during (2), and after (3) bath application of 300 $\boldsymbol{\mu} \mathrm{M}$ ACh. $\boldsymbol{E}$, Time course of ACh effect on elPSC amplitude (E1) and holding current (E2) (same cell as shown in $\boldsymbol{D})$. $\boldsymbol{F}$, Summary of data obtained with $300 \mu \mathrm{m}$ ACh in 5 cells. ${ }^{* *} p<0.01$; ${ }^{* * *} p<0.001$. I hold Holding current; norm, normalized.

electrical stimuli via an electrode positioned in stratum radiatum. Bath-applied ACh (10 mM) reversibly depressed stimulus-evoked IPSCs (eIPSCs; mean depression, $56 \pm 6 \%$; recovery to $78 \pm 4 \%$ of baseline; $n=5 ; p<0.001$ ) (Fig. $1 A-C$ ). The depression was not accompanied by detectable changes in eIPSC kinetics (supplemental Table 1, available at www.jneurosci.org as supplemental material). The effect of ACh on eIPSCs was completely blocked by the $\alpha 7$-selective blocker MLA (100 nM; ACh in MLA, $95 \pm 6 \%$ of baseline; $n=5 ; p=0.84$ ). MLA also abolished the ACh-evoked increase in holding current. Application of a lower concentration of ACh $(300 \mu \mathrm{M})$ also evoked a reversible decrease in eIPSCs $(29 \pm 5 \%$ reduction; $n=5 ; p<0.01)$ (Fig. $1 D-F)$, although this was smaller than that seen with $10 \mathrm{~mm}$. Bath perfusion of $100 \mu \mathrm{M}$ ACh did not significantly depress eIPSCs (data not shown).

Although these results are consistent with an action of $\alpha 7$ $\mathrm{nAChRs}$ on GABAergic signaling, MLA at $100 \mathrm{~nm}$ has been reported to act on other subtypes of nAChRs (Mogg et al., 2002). Moreover, the concentration of $\mathrm{ACh}$ required to attenuate
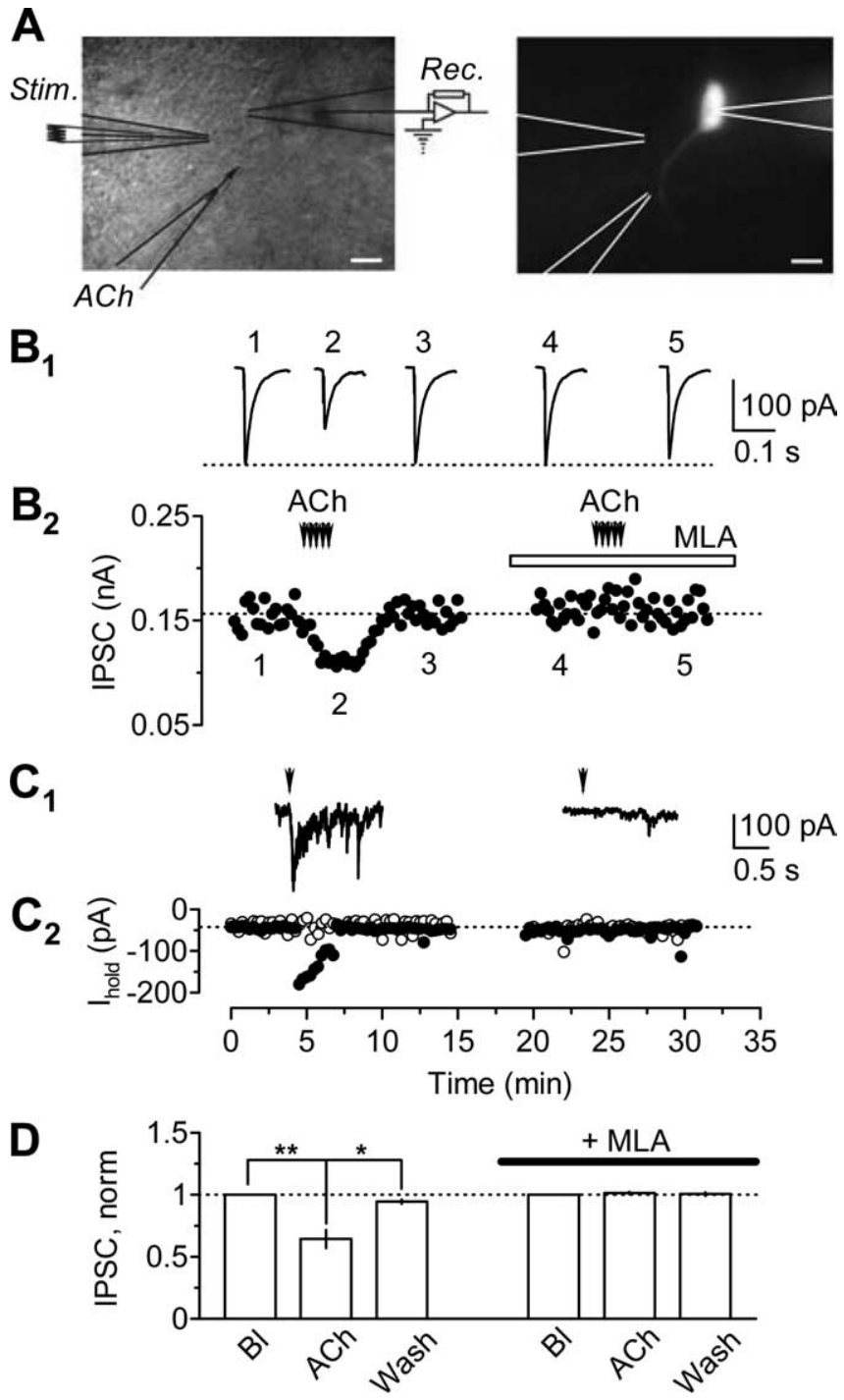

Figure 2. Brief applications of ACh reversibly depress elPSCs in interneurons. A, Differential interference contrast (left) and epifluorescence (right) images showing the arrangement of stimulating electrode (Stim.), pressure-application pipette ( $\mathrm{ACh} ; 1 \mathrm{~mm}$ ), and recording pipette (Rec.). Scale bar, $20 \mu \mathrm{m}$. B1, elPSCs recorded from an interneuron during baseline (1), $3 \mathrm{~min}$ after pressure application of $1 \mathrm{~mm} \mathrm{ACh} \mathrm{(2),} \mathrm{and} \mathrm{after} \mathrm{a} 10 \mathrm{~min}$ recovery period (3), and subsequently in the presence of $10 \mathrm{~nm}$ MLA before (4) and after (5) ACh application. B2, Time course of ACh effect on elPSCs and blockade of the effect by MLA, showing the times at which the traces in $\boldsymbol{B} 1$ were obtained (1-5). IPSCs were evoked every $15 \mathrm{~s}$ (traces, averages of 10 successive trials at the times indicated). Arrowheads indicate pressure application of ACh, $2 s$ before IPSC $s$ were evoked, repeated 10 times. C1, Representative traces showing ACh-evoked inward current (10 ms pulse at $10 \mathrm{psi}$ ) in control conditions (left) and in the presence of $10 \mathrm{~nm} \mathrm{MLA} \mathrm{(right).} \mathrm{C2,} \mathrm{Time}$ course of the ACh effect on the holding current measured immediately before (open symbols) and at a time corresponding to the peak of (filled symbols) the ACh-evoked inward currents in the same neuron. $\boldsymbol{D}$, Summary of data obtained in nine cells under control conditions and six cells in MLA. ACh, 3 min after the last ACh application; Wash, recovery 10 min after the last ACh application; the data obtained in the presence of MLA (+ MLA) were renormalized to a new baseline. ${ }^{*} p<0.05 ;{ }^{* *} p<0.01$. I hold Holding current; norm, normalized.

eIPSCs was higher than expected from the $\mathrm{EC}_{50}$ at $\alpha 7 \mathrm{nAChRs}$ (Alkondon et al., 1997b; Papke and Porter Papke, 2002). A possible explanation is that ACh is hydrolyzed by extracellular cholinesterases, reducing the effective concentration reaching the nAChRs. Furthermore, some $\alpha 7$ nAChRs may have been desensitized by the slow wave of ACh penetrating the slice. We therefore delivered ACh locally via pressure application while evoking IPSCs (Fig. 2A). Brief pressure application of ACh (pipette con- 
centration, $1 \mathrm{~mm}$ ) reversibly depressed eIPSCs (36 $\pm 7 \%$ depression; $p<0.01 ; n=9$ ) (Fig. $2 B$ ) as well as evoking fast inward currents (Fig. 2C). Notably, the depression of eIPSCs evolved more slowly than the ACh-evoked inward currents and persisted for several minutes after return of the holding current to baseline (see Fig. 2C, example traces). A low concentration of MLA (10 $\mathrm{nM})$ fully blocked both the inward currents and the modulation of eIPSCs (ACh in MLA, $101 \pm 1 \%$ of baseline; $n=6 ; p=0.82$ ) (Fig. $2 B-D$ ), consistent with the sensitivity of $\alpha 7 \mathrm{nAChRs}$ to this blocker.

To test further whether $\alpha 7 \mathrm{nAChRs}$ accounted for the depression of eIPSCs, we applied two selective agonists. Choline is a low-affinity but relatively nondesensitizing agonist at $\alpha 7$ $\mathrm{nAChRs,} \mathrm{with} \mathrm{an} \mathrm{EC}_{50} \sim 20$-fold greater than for ACh (Alkondon et al., 1997b; Papke and Porter Papke, 2002). We first verified that pressure-applied choline (pipette concentration, $10 \mathrm{~mm} ; 10-15$ $\mathrm{ms}$ at $10 \mathrm{psi}$ ) elicited a robust inward current in all interneurons tested $(613 \pm 36 \mathrm{pA} ; n=5$; data not shown), which was blocked by $30 \mathrm{~nm}$ MLA. Having established that choline activates nAChRs with a pharmacological profile consistent with $\alpha 7$, we asked whether choline could decrease the amplitude of eIPSCs. Bathapplied choline (1 mM) reversibly depressed eIPSCs in stratum radiatum interneurons $(22 \pm 2 \%$ inhibition; $n=4 ; p<0.01)$ (Fig. 3A). This effect was blocked by MLA (data not shown). When repeated in pyramidal neurons, the effect of choline was much smaller ( $8.6 \pm 1.5 \%$ inhibition; $n=6)$ albeit significant at $p<0.01$ (Fig. 3A), consistent with a lower density of $\alpha 7$ nAChRs (Alkondon et al., 1998; Frazier et al., 1998a).

$\alpha 7$ nAChRs are also activated by the highly potent and selective agonist 3-(4-hydroxy,2-methoxybenzylidene)anabaseine [4OH-GTS21 (GTS)] (Papke et al., 2000). Bath application of this agonist elicited a concentration-dependent reduction of eIPSC amplitude in interneurons: $13 \pm 3 \%(n=6 ; p<0.01)$ and $30 \pm 6 \%(n=8 ; p<0.01)$ for 3 and $10 \mu \mathrm{M}$ GTS, respectively. This reduction was reversed by addition of $30 \mathrm{~nm}$ MLA (recovery to $102 \pm 7 \%$ of baseline; $n=7 ; p=0.73$ ) (Fig. $3 B, C$ ).

We thus conclude that $\alpha 7 \mathrm{nAChRs}$ robustly depress GABAergic eIPSCs recorded in hippocampal interneurons.

\section{$\alpha 7$ nAChR-mediated depression of IPSCs is postsynaptically mediated}

nAChRs have previously been reported to affect neurotransmitter release, although in the opposite direction from that required to explain the inhibition of eIPSCs (Seguela et al., 1993; McGehee et al., 1995; Gray et al., 1996). We asked whether the $\alpha 7 \mathrm{nAChR}-$ mediated depression of eIPSCs was accompanied by a change in PPR, which is sensitive to manipulations that alter transmitter release probability (Manabe et al., 1993). We observed a small, albeit significant, decrease in PPR with $10 \mu \mathrm{M}$ GTS. The PPR decreased on average from $0.81 \pm 0.07$ to $0.65 \pm 0.08(n=6 ; p<$ $0.05)$ and recovered to $0.84 \pm 0.09$ in the presence of MLA $(n=$ $6 ; p=0.27$ for baseline vs MLA). This change in PPR is consistent with an increase in release probability, although it accompanied a net decrease in the amplitude of the first eIPSC of $25 \pm 6 \%(n=$ $6 ; p<0.01$ ) (Fig. 4A). A similar result was observed after bath application of $10 \mathrm{~mm}$ ACh: the PPR decreased from $0.97 \pm 0.11$ to $0.75 \pm 0.06(n=5 ; p<0.05)$ and recovered after washout to $0.99 \pm 0.11(p=0.34)$. This change in PPR accompanied a reduction of the first eIPSC of $56 \pm 6 \%(p<0.001)$ (Fig. $4 B)$.

The change in PPR is strongly suggestive of a presynaptic increase in GABA release probability, consistent with previous reports on glutamate release. Consistent with this, ACh application also reversibly increased the frequency of spontaneous IPSCs
A

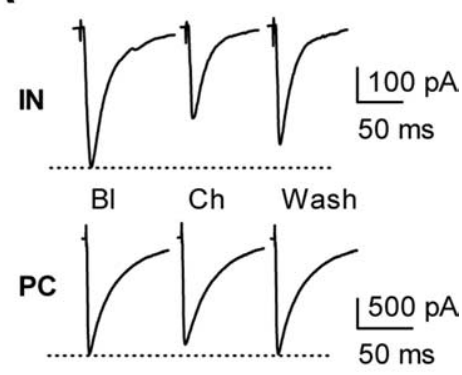

B

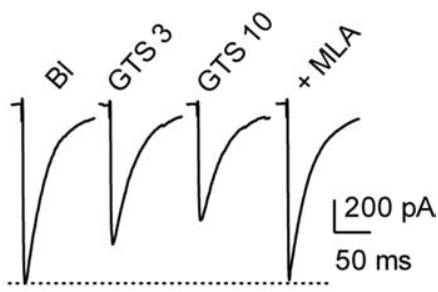

C

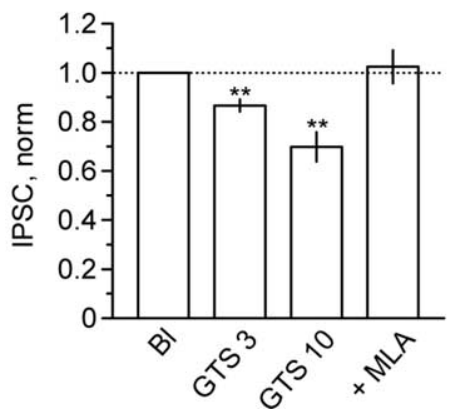

Figure 3. Selective $\alpha 7 \mathrm{nAChR}$ agonists depress elPSCs in interneurons to a larger extent than in pyramidal cells. $A$, Representative elPSCs recorded in stratum radiatum interneurons (IN) and pyramidal cells $(\mathrm{PC})$ in the $\mathrm{CA} 1$ region before $(\mathrm{BI})$, during $(\mathrm{Ch})$, and after (Wash) bath application of $1 \mathrm{~mm}$ choline. $\boldsymbol{B}$, Representative traces showing concentration-dependent depression of elPSCs by the selective $\alpha 7 \mathrm{nAChR}$ agonist GTS and inhibition of the GTS effect by $30 \mathrm{~nm} \mathrm{MLA} \mathrm{(+}$ $M L A) . C$, Averaged results showing the effect of 3 and $10 \mu \mathrm{M}$ GTS and reversal of the effect of 10 $\mu \mathrm{M}$ GTS by $30 \mathrm{~nm} \mathrm{MLA} \mathrm{(BI,} n=8$; GTS $3, n=6$; GTS 10, $n=8 ;+\mathrm{MLA}, n=7)$. ${ }^{* *} p<0.01$. norm, Normalized.

(sIPSCs) by $193 \pm 18 \%$ (from $3.4 \pm 0.3$ to $6.3 \pm 0.3 \mathrm{~Hz} ; n=7$; $p<0.05$ ) (supplemental Table 2, available at www.jneurosci.org as supplemental material). This increase in frequency was accompanied by a $9 \pm 3 \%$ decrease in sIPSC amplitude (from $59 \pm 7$ to $49 \pm 7 \mathrm{pA} ; n=7 ; p<0.05)$. Both the increase in frequency and the decrease in amplitude were reversible after wash $(2.6 \pm 0.5$ $\mathrm{Hz}, p=0.06 ; 63 \pm 4 \mathrm{pA}, p=0.33)$. In the presence of $100 \mathrm{nM}$ MLA, neither the frequency nor the amplitude of sIPSCs was affected by ACh [baseline (Bl), $3.6 \pm 1.1 \mathrm{~Hz}, 61 \pm 7 \mathrm{pA}$; ACh, $3.4 \pm 0.8 \mathrm{~Hz}, 61 \pm 8 \mathrm{pA} ; n=7 ; p=0.25$ and $p=0.09$, respectively) (supplemental Table 2, available at www.jneurosci.org as supplemental material). In seven other cells, we further confirmed that ACh enhanced GABA release by recording action potential-independent miniature IPSCs (mIPSCs) in the presence of tetrodotoxin (TTX; $2 \mu \mathrm{M}$ ) (Fig. 4C): bath application of $\mathrm{ACh}(10 \mathrm{~mm})$ elicited a reversible $317 \pm 87 \%$ increase in mIPSC frequency (from $1.8 \pm 0.5 \mathrm{~Hz}$ in $\mathrm{Bl}$ to $3.8 \pm 0.2 \mathrm{~Hz}$ in $\mathrm{ACh} ; n=7$; $p<0.01$ ) (Fig. 4D1,E, right). This increase in frequency was accompanied by a $54 \pm 4 \%$ decrease in mIPSCs amplitude (from $36 \pm 4 \mathrm{pA}$ in $\mathrm{Bl}$ to $19 \pm 3 \mathrm{pA}$ in $\mathrm{ACh} ; n=7 ; p<0.01$ ) (Fig. 4 D2, $E$, left). After $10 \mathrm{~min}$ washout, both the amplitude and the frequency of the mIPSCs returned to baseline values (Fig. $4 C-E$ ). 
$A_{1}$

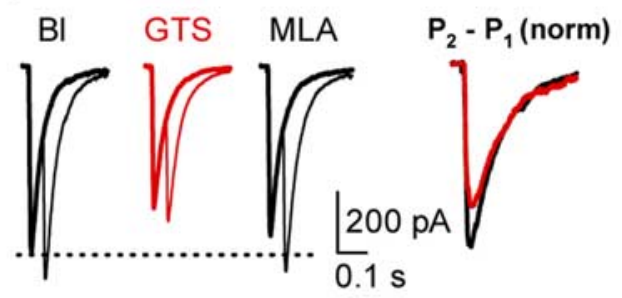

$\mathrm{B}_{1}$

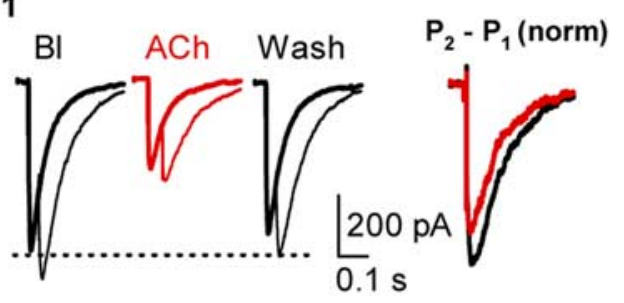

C

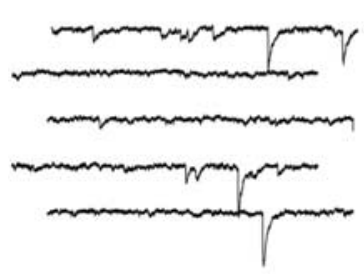

\section{$D_{1}$}

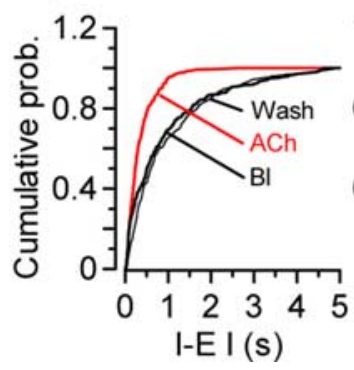

$\mathrm{BI}$

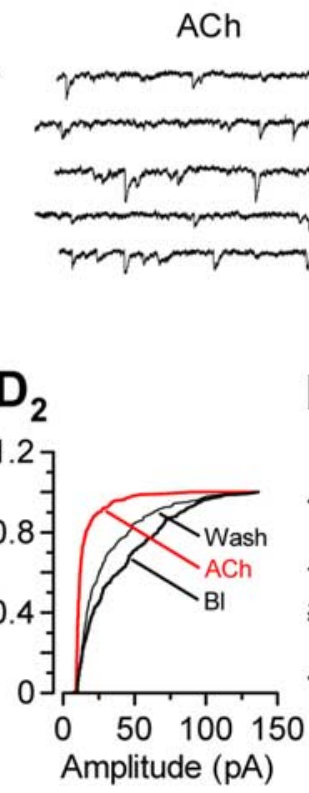

$A_{2}$

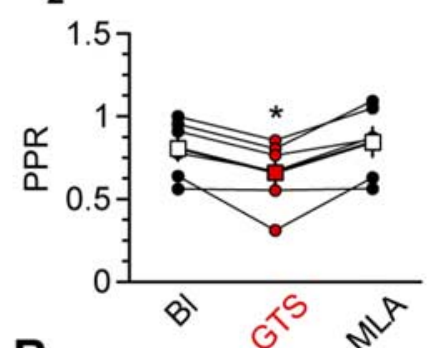

$\mathrm{B}_{2}$

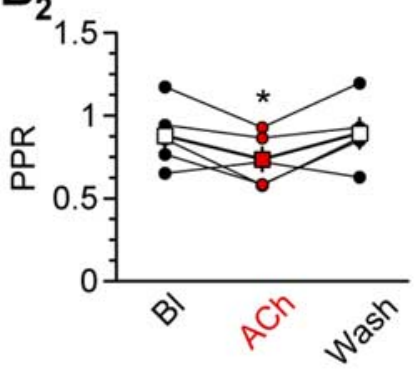

Wash

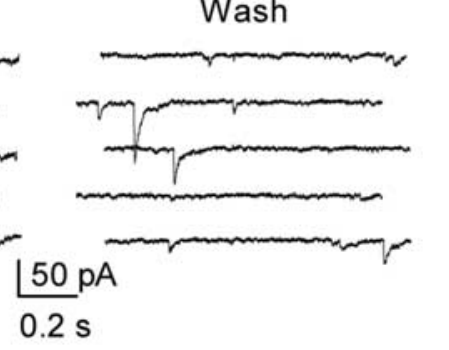

E

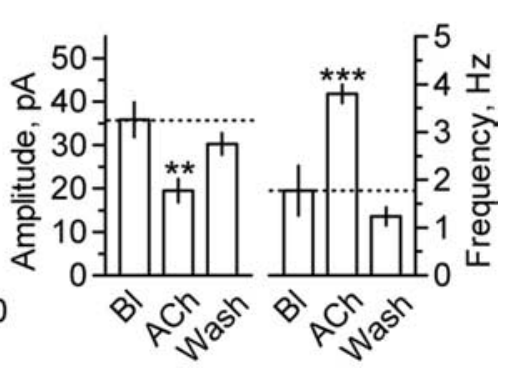

Figure 4. Evidence for opposing presynaptic and postsynaptic effects of $\alpha 7 \mathrm{nAChRs}$ on elPSCs. $\boldsymbol{A}$, Paired-pulse ratio measurement and effect of $\alpha 7 \mathrm{nAChR}$ activation. A1, Sample traces show IPSCs evoked by either one (thick line) or two (thin line) stimuli, before (BI) and during (red traces) bath application of $10 \mu \mathrm{M}$ GTS and after washout and bath application of $100 \mathrm{~nm}$ MLA. The superimposed traces on the right were obtained by subtracting the first eIPSC from the paired-stimulus response to reveal the shape of the second eIPSC $\left[P_{2}-P_{1}\right.$, normalized (norm)]. The traces were then normalized by the amplitude of the first eIPSC and are shown before (black) and during (red) GTS application. The decreased relative amplitude of the second eIPSC indicates a decrease in PPR. A2, Results pooled from six experiments, showing a decrease in PPR during GTS application (red symbols), which accompanied a reduction of the first elPSC by $24.5 \pm 5.9 \%(n=6 ; p<0.01$; circles represent individual experiments; squares represent means). B1, Representative traces obtained in one interneuron before (BI), during (ACh; red), and after (Wash) bath application of $10 \mathrm{~mm} A C h$. B2, Results pooled from five experiments showing the effect of ACh on PPR. ACh reduced the elPSC amplitude by $56 \pm 6 \%(n=5 ; p<0.001$; circles represent individual experiments; squares represent means). $C$, Representative traces showing miniature IPSCS recorded in an interneuron in the presence of TTX (2 $\mu \mathrm{m})$ before (BI) and during ACh application (ACh) and after 10 min washout (Wash). In each condition, traces represent a continuous recording period of 5 s. D, Cumulative probability (prob.) plots for the interevent interval (I-E I; D1) and the amplitude (D2) from the cell shown in $\mathbf{C}$ at baseline (BI), during ACh application (ACh; red line), and after washout (Wash). $\boldsymbol{E}$, Averaged results obtained from seven cells showing the effect of ACh on the mIPSCs amplitude (left) and frequency (right). ${ }^{*} p<0.05 ;{ }^{* *} p<0.01 ;{ }^{* * *} p<0.001$.

The alternative explanation for the reduction in eIPSC amplitude is that, in parallel with a modest presynaptic enhancement of GABA release, $\alpha 7 \mathrm{nAChRs}$ also cause a more profound postsynaptic decrease in the response to GABA. We tested this by mea- suring the effect of bath-applied ACh on currents evoked in hippocampal interneurons by pressure application of GABA (100 $\mu \mathrm{M} ; 5-10 \mathrm{~ms}$ at $10 \mathrm{psi}$ ), to bypass presynaptic transmitter release mechanisms. We verified that GABA-evoked currents were fully blocked by $100 \mu \mathrm{M}$ picrotoxin at the end of the experiment (data not shown). GABA-evoked currents were profoundly depressed by $10 \mathrm{~mm} \mathrm{ACh}$ $(55 \pm 1 \% ; n=5 ; p<0.001$ ) (Fig. $5 A, B)$. When applied twice in the same cell, ACh evoked a robust, reversible, and reproducible depression of the GABA-evoked current (depression, $56 \pm 4 \%$ and $53 \pm 5 \%$ for the first and second $\mathrm{ACh}$ applications, respectively; $n=6 ; p=0.083$ for comparison), with full recovery after washout (98 \pm 2 and $96 \pm 1 \%$ for the two applications; $p=0.79)$. MLA (100 nM) completely blocked the depression of the GABA current when added to the perfusion solution before the second application of ACh (Fig. $5 A, B$ ).

The depression of GABA-evoked currents was concentration dependent: 300 $\mu \mathrm{M}$ ACh produced a $17 \pm 3 \%$ depression $(n=4 ; p<0.001)$, whereas $100 \mu \mathrm{M} \mathrm{ACh}$ was ineffective $(1.0 \pm 2.5 \% ; n=4 ; p=$ 0.34 ) (Fig. $5 C, D$ ). These results are consistent with the effects of different concentrations of ACh on eIPSCs (Fig. 1). As mentioned above, a possible explanation for the failure to evoke a depression of GABA-evoked currents with $100 \mu \mathrm{M}$ ACh is that cholinesterase activity greatly lowers the effective concentration reaching the receptors. We therefore repeated the $100 \mu \mathrm{M}$ ACh application in the presence of the cholinesterase blocker eserine $(5 \mu \mathrm{M})$. This revealed a robust depression of the GABA-evoked current ( $22 \pm 4 \% ; n=7$; $p<0.05$ ), accompanied by a small increase in holding current (Fig. 6).

A potential confounding factor in the above experiments is that prolonged whole-cell recording may have perturbed the signaling cascade from $\alpha 7 \mathrm{nAChRs}$ to $\mathrm{GABA}_{\mathrm{A}}$ receptors. To minimize this source of artifact, we examined the effect of nAChRs noninvasively, by applying the amphotericin B perforated-patch recording method (Horn and Marty, 1988). With this recording method, $10 \mu \mathrm{M}$ GTS produced an even larger depression of eIPSC amplitude than with whole-cell recording $[43 \pm 7 \% ; n=3 ; p<0.001$ (supplemental Fig. 2, available at www. jneurosci.org as supplemental material) compared with $30 \pm 6 \% ; n=8$ (Fig. $3 B, C$ ); $p<0.05$ for comparison of perforated-patch vs whole-cell]. The reduction was fully reversed by $100 \mathrm{~nm}$ MLA. This implies that whole-cell recording may underestimate the magnitude of the depression 
$A_{1}$

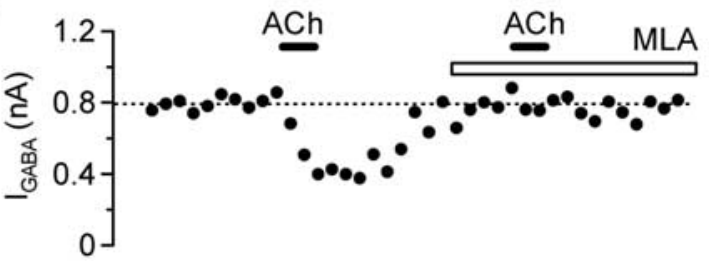

$A_{2}$

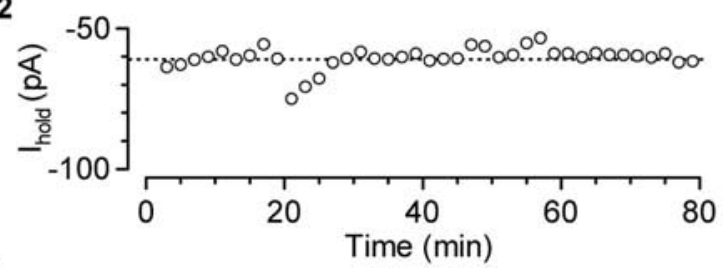

B

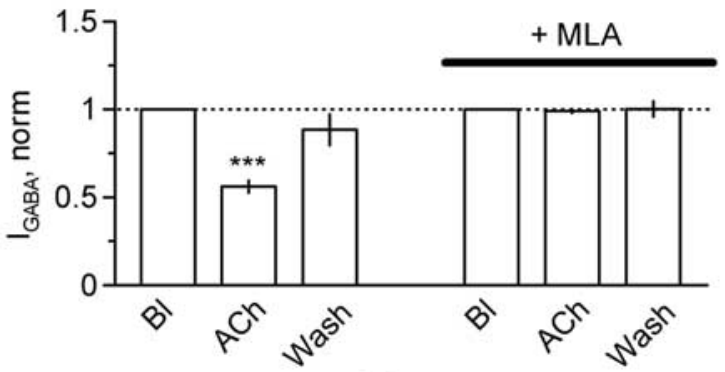

C

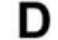

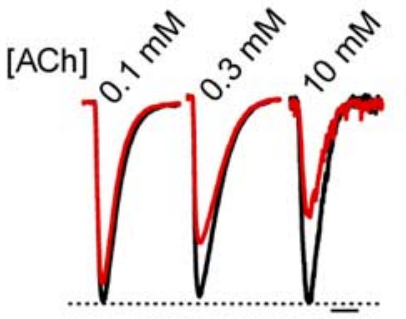

$0.2 \mathrm{~s}$

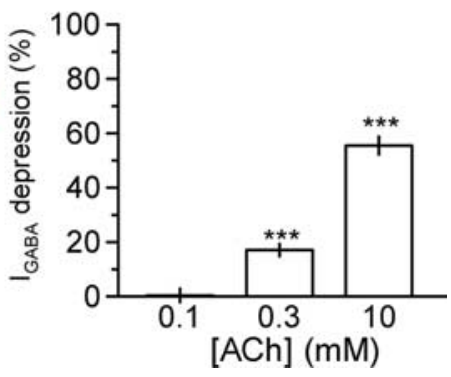

Figure 5. ACh produces an $\alpha 7 \mathrm{nAChR}$-mediated and concentration-dependent reduction of GABA-evoked currents. $\boldsymbol{A}$, Time course plot showing the effect of ACh $(10 \mathrm{~mm})$ on the agonistevoked GABA current amplitude (A1) and holding current (A2) and blockade of the effect by $M L A . B$, Averaged results from five experiments. The data obtained in the presence of $M L A$ were renormalized to a new baseline. $C$, Representative traces showing currents evoked by GABA application before (black) and during (red) bath application of $0.1(n=4), 0.3(n=4)$, and 10 $\mathrm{mm}(n=5) \mathrm{ACh}$ (each trace is normalized to the peak amplitude of the GABA current before ACh application). D, Pooled results showing ACh-evoked depression of GABA currents. ${ }^{* * *} p<$ 0.001. I hold , Holding current; norm, normalized.

of eIPSCs and is again consistent with a postsynaptic site of action.

Because $\alpha 7 \mathrm{nAChR}$ activation leads to opening of a cationselective conductance in the interneurons, it is reasonable to ask whether the decrease of $\mathrm{GABA}_{\mathrm{A}}$ receptor-mediated currents could simply be an electrical shunting artifact. This is highly unlikely, because the time course of the increase in holding current after application of ACh was clearly dissociated from the time course of the depression of eIPSCs or GABA-evoked currents (Figs. 1, 2, 5, 6). We nevertheless tested this hypothesis by injecting simulated synaptic conductances while recording from interneurons in dynamic current-clamp mode. ACh (10 mM) had no detectable effect on simulated IPSPs, whereas stimulus-evoked IPSPs recorded in parallel were profoundly and reversibly decreased (for additional discussion, see supplemental Fig. 3 and
A
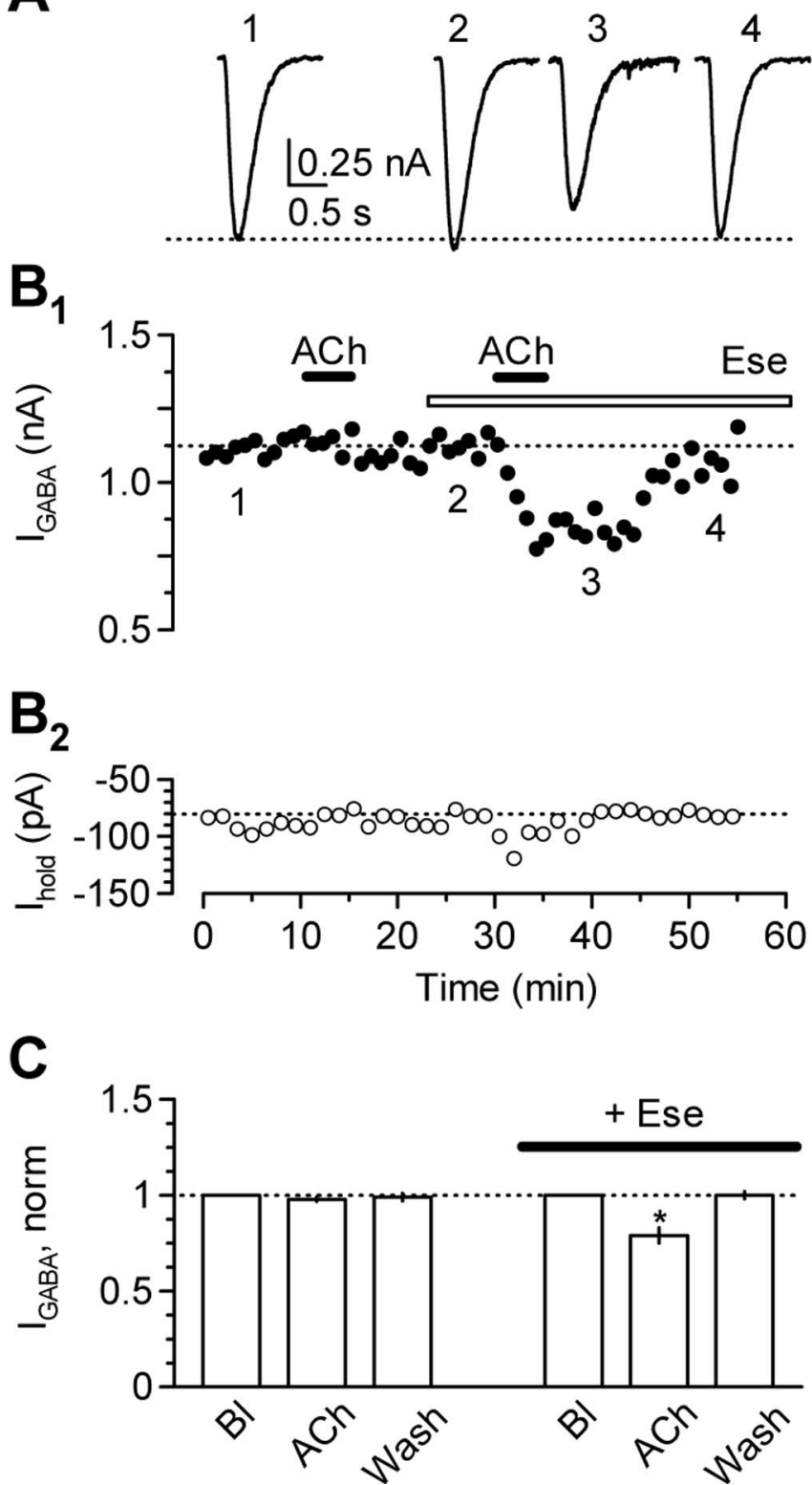

Figure 6. Cholinesterase blockade reveals depression of GABA-evoked currents by a low concentration of ACh. $A$, Representative GABA-evoked currents recorded during baseline (1) and in the continued presence of eserine before (2) and during (3) bath application of ACh and after washout (4). $\boldsymbol{B}$, Time course plot showing the effect of ACh on the GABA-evoked current amplitude ( $\boldsymbol{B}$ 1) and holding current ( $\boldsymbol{B}$ 2), before and after addition of eserine [Ese; same cell as (A)]. C, Summary data obtained in five and seven cells in the absence and presence of eserine, respectively. The data obtained in the presence of eserine were renormalized to a new baseline. ACh, After $100 \mu \mathrm{M}$ ACh application; Wash, recovery after 10 min washout. ${ }^{*} p<0.05$. I hold Holding current; norm, normalized.

legend, available at www.jneurosci.org as supplemental material).

We thus conclude that ACh, choline, and GTS act on $\alpha 7$ $n A C h R s$ to depress GABAergic transmission and that this effect can be explained by a postsynaptic action on $\mathrm{GABA}_{\mathrm{A}}$ receptors that outweighs a small presynaptic enhancement in GABA release. However, the results do not exclude the possibility that $\alpha 7$ nAChRs act indirectly, by exciting surrounding neurons and causing the release of other neurotransmitters, which influence $\mathrm{GABA}_{\mathrm{A}}$ receptors on the recorded neuron. Among neurotransmitters released from neighboring interneurons, GABA itself 
could conceivably accumulate in the extracellular space, leading to receptor desensitization. Such a mechanism has been suggested to contribute to the depression of GABAergic transmission by kainate receptors (Frerking et al., 1999). We therefore repeated the application of $10 \mathrm{~mm}$ ACh while blocking action potential generation with TTX $(2 \mu \mathrm{M})$ (supplemental Fig. 4, available at www.jneurosci.org as supplemental material). An almost identical depression of GABA-evoked currents was obtained $(61 \pm 13 \%$, compared with $56 \pm 3 \%$ without TTX; $p=0.24)$, confirming that the effect of $\alpha 7 \mathrm{nAChR}$ activation did not depend on spontaneous activity in the slice. These results show that postsynaptic $\alpha 7 \mathrm{nAChRs}$ decrease GABA currents directly and argue against any involvement of presynaptic structures or sodium channels, which may play a role in choline-evoked modulation of $\mathrm{GABA}_{\mathrm{A}}$ receptor-mediated currents in hippocampal neurons (Alkondon et al., 2000).

\section{The $\alpha 7 \mathrm{nAChR}$ action on $\mathrm{GABA}_{\mathrm{A}}$ receptors involves $\mathrm{Ca}^{2+}$ and $\mathrm{PKC}$}

In all of the above experiments, whether the agonist was applied by bath or by pressure application, the $\alpha 7 \mathrm{nAChR}$-mediated depression of $\mathrm{GABA}_{\mathrm{A}}$ receptor-mediated currents developed over several minutes. We examined this further by pressure applying the $\mathrm{GABA}_{\mathrm{A}}$ receptor agonist muscimol $(10 \mu \mathrm{M} ; 5-10 \mathrm{~ms}$ at 10 psi), either alone or simultaneously with choline (10 mM; 10-20 $\mathrm{ms}$ at $10 \mathrm{psi}$ ), delivered via a second pipette. After pressure application of choline, the $\mathrm{GABA}_{\mathrm{A}}$ receptor-mediated current decreased progressively to $73 \pm 2 \%$ of baseline $(n=3 ; p<0.001)$ over several minutes and recovered only slowly (although fully) after terminating the choline coapplication (104 $\pm 2 \%$ of baseline; $p=0.053$ ) (supplemental Fig. 5, available at www. jneurosci.org as supplemental material). The time course of the depression of muscimol-evoked currents by choline was similar to that of the depression of GABA-evoked currents by pressureapplied ACh (Fig. 2B). This suggests that a slow postsynaptic transduction cascade is responsible for the effect, because choline is unlikely to accumulate slowly and persist at high concentrations for several minutes after highly localized pressure application.

A potential candidate messenger that mediates the effect of ACh, choline, or GTS is $\mathrm{Ca}^{2+}$ entering through $\alpha 7$ nAChRs (Mulle et al., 1992). However, direct depolarization to $-20 \mathrm{mV}$ for 30 s to evoke $\mathrm{Ca}^{2+}$ influx via voltage-gated $\mathrm{Ca}^{2+}$ channels was without effect on GABA currents (data not shown). Nevertheless, by analogy with the role of NMDA receptors in long-term potentiation, the synaptic localization of $\alpha 7$ receptors (Fabian-Fine et al., 2001; Kawai et al., 2002) may allow $\mathrm{Ca}^{2+}$ entering via the $n A C h R s$ to gain privileged access to an effector cascade that alters $\mathrm{GABA}_{\mathrm{A}}$ receptors. We tested the role of $\mathrm{Ca}^{2+}$ ions by repeating the ACh application while recording from hippocampal interneurons with a pipette containing a high concentration of the $\mathrm{Ca}^{2+}$ chelator BAPTA $(10 \mathrm{~mm})$. We first verified that pressure application of ACh evoked inward currents in interneurons recorded with a BAPTA-containing pipette, similar to those evoked in cells recorded with EGTA, arguing that $\mathrm{Ca}^{2+}$ chelation does not impair ion flux through nAChRs. In contrast to the situation observed with 2 mm EGTA (Fig. 7A,C,E), bath application of ACh failed to depress GABA-evoked currents and instead induced a small albeit significant increase (16 $\pm 8 \%$; $n=5 ; p<$ 0.05 ) (Fig. $7 B, D, F)$. ACh application was, however, accompanied by an increase in holding current $(19.0 \pm 4.1 \%)$, comparable with that seen in the experiments with EGTA $(21 \pm 7 \% ; n=5$; $p=0.64$ for comparison between EGTA and BAPTA), implying

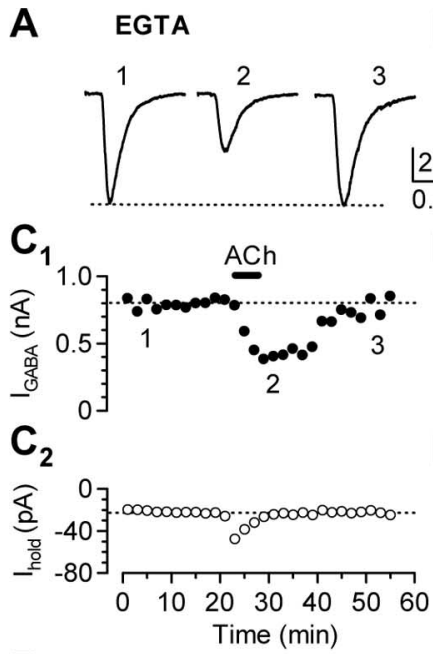

B BAPTA
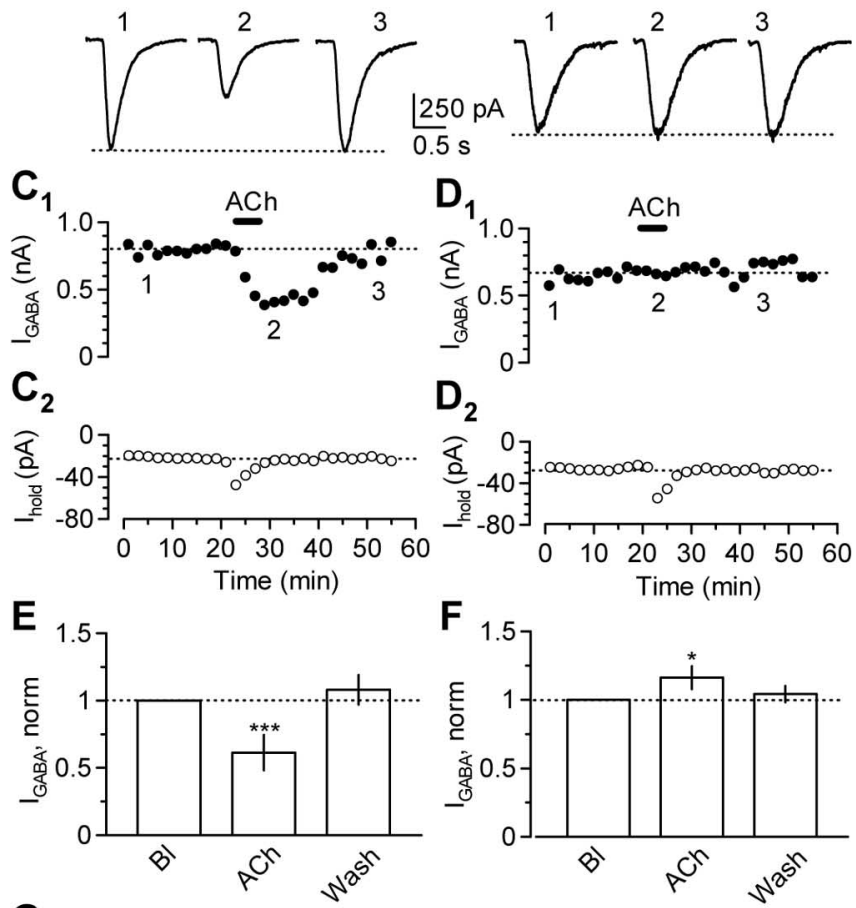

G
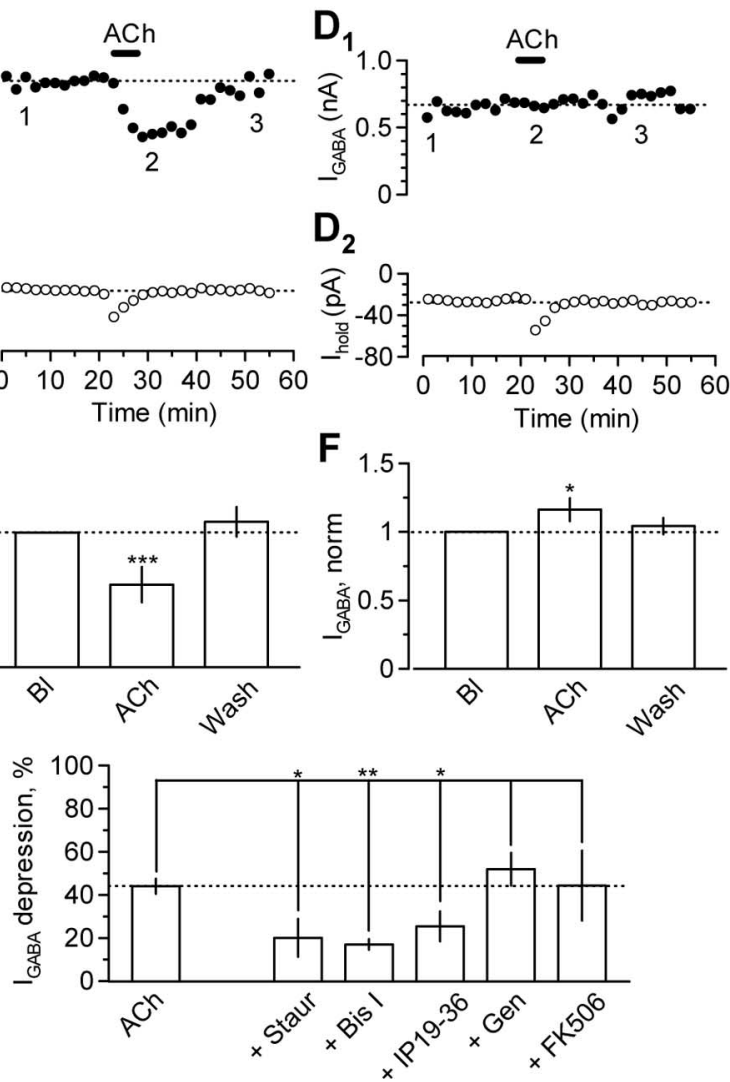

Figure 7. Depression of $\mathrm{GABA}_{A}$ receptor-mediated currents requires postsynaptic $\mathrm{Ca}^{2+}$ elevation and involves PKC. $A, B$, Representative traces showing GABA-evoked currents recorded with an intracellular solution containing $2 \mathrm{~mm}$ EGTA $(\boldsymbol{A})$ or $10 \mathrm{~mm}$ BAPTA (B) at baseline (1), during bath application of $10 \mathrm{~mm} A C h(2)$, and after washout of $A C h$ (3). C, D, Time course of the effect of $A C h$ on $G A B A$-evoked currents $(C 1, D 1)$ and on the holding current $(\mathbf{C}, \mathbf{D 2})$ for the cells shown in $\boldsymbol{A}$ and $\boldsymbol{B}$. $\boldsymbol{E}, \boldsymbol{F}$, Averaged data pooled from five experiments with $2 \mathrm{~mm}$ intracellular EGTA $(\boldsymbol{E})$ and five experiments with $10 \mathrm{~mm}$ intracellular BAPTA $(\boldsymbol{F})$. $\boldsymbol{G}$, Summary of the effects of kinase and calcineurin inhibitors on the ACh-mediated depression of GABA-evoked currents. The inhibition of GABA currents observed with ACh application alone (from Fig. $5 B$ ) is shown on the left for comparison. Staurosporine ( + Staur; $200 \mathrm{~nm} ; n=6$ ), bisindolylmaleimide I ( Bis I; $1 \mu \mathrm{m} ; n=5)$, PKC inhibitory peptide (+ IP19-36; $4 \mu \mathrm{m}$ added to the patch-pipette solution; $n=6$ ), genistein ( + Gen; $30 \mu \mathrm{m} ; n=3$ ), and FK506 (added at $0.5 \mu \mathrm{m}$ in the patch-pipette solution; $n=3$ ) were used. ${ }^{*} p<0.05 ;{ }^{* *} p<0.01 ;{ }^{* * *} p<0.001$. I hold , Holding current; norm, normalized.

that the cation flux through $\alpha 7 \mathrm{nAChRs}$ could be dissociated from the depression of $\mathrm{GABA}_{\mathrm{A}}$ receptor-mediated currents. The effect of BAPTA further argues against shunting and/or desensitization as the explanation for the $\alpha 7 \mathrm{nAChR}$ agonist-evoked depression of $\mathrm{GABA}_{\mathrm{A}}$ receptor-mediated currents.

The results above imply that $\alpha 7 \mathrm{nAChR}$ activation normally depresses $\mathrm{GABA}_{\mathrm{A}}$ receptor-mediated currents via a $\mathrm{Ca}^{2+}$ dependent intracellular cascade. Experimental manipulations of several intracellular signaling mechanisms, principally involving protein phosphorylation, have been shown to modulate the function and/or number of $\mathrm{GABA}_{\mathrm{A}}$ receptors expressed in neurons or cultured neurons [for review, see Kittler and Moss (2003) and Luscher and Keller (2004)]. To determine which pathway is involved in the $\alpha 7$ nAChR-mediated inhibition of GABAergic sig- 
naling in interneurons, we repeated the application of ACh in the presence of different inhibitors (each bath applied for at least 20 min before testing the effect of ACh) (Fig. 7G). Genistein (30 $\mu \mathrm{M}$ ), a tyrosine kinase inhibitor, did not prevent the inhibition of GABA-evoked currents $(52 \pm 8 \% ; n=3)$ [in a separate study, we have verified that this concentration is sufficient to interfere with NMDA receptor-mediated signaling in stratum radiatum interneurons, implying that the drug penetrated the slice (K. P. Lamsa and D. M. Kullmann, unpublished results)]. In contrast, bath application of staurosporine $(200 \mathrm{nM})$, a broad-spectrum protein kinase inhibitor, markedly attenuated the ACh-evoked inhibition of GABA currents ( $20 \pm 9 \%$; $n=6 ; p<0.01$ for comparison with ACh effect without staurosporine). A possible explanation for the effect of staurosporine is that it interfered with PKC, activation of which has been shown to negatively modulate $\mathrm{GABA}_{\mathrm{A}}$ receptors (Sigel and Baur, 1988; Brandon et al., 2000). We therefore applied ACh after preincubating in BisI $(1 \mu \mathrm{M})$, a more selective PKC inhibitor. This treatment also attenuated the effect of ACh (17 $\pm 3 \% ; n=5 ; p<0.01$ for comparison with ACh alone). We further tested the role of PKC by including the specific inhibitory peptide IP19-36 (4 $\mu \mathrm{M})$, which corresponds to the autoinhibitory domain of the enzyme (Smith et al., 1990), in the pipette solution. This also significantly attenuated the effect of ACh on GABA-evoked currents $(23 \pm 6 \% ; n=6 ; p<0.05$ for comparison to ACh alone). The phosphatase calcineurin has also been reported to mediate long-term depression of GABA IPSPs in the CA1 region of the hippocampus (Lu et al., 2000; Wang et al., 2003). However, when calcineurin was inhibited by including 0.5 $\mu \mathrm{M}$ FK506 in the patch pipette, the action of ACh on GABA currents was no different from in the control experiments ( $44 \pm$ $16 \% ; n=3 ; p=0.55)$. These results are most simply explained by the hypothesis that $\mathrm{Ca}^{2+}$ entering through $\alpha 7 \mathrm{nAChRs}$ activates $\mathrm{PKC}$, which in turn acts on $\mathrm{GABA}_{\mathrm{A}}$ receptors in interneurons. Nevertheless, none of the PKC blockers fully abolished the effect of ACh, suggesting an additional PKC-independent pathway leading from $\mathrm{Ca}^{2+}$ influx via $\alpha 7 \mathrm{nAChRs}$ to $\mathrm{GABA}_{\mathrm{A}}$ receptor modulation.

\section{Endogenous ACh release evokes heterosynaptic depression of GABAergic signaling}

What is the physiological relevance of the phenomena described in the present study? The cholinergic projection to the hippocampus is diffuse and enters via the fornix/fimbria (Mesulam, 2004b), although some intrinsic cholinergic neurons also exist (Frotscher et al., 1986). We attempted to detect a role for endogenous ACh release by performing a two-pathway experiment, to determine whether activation of cholinergic axons could affect a test eIPSC. We monitored a monosynaptic eIPSC in stratum radiatum interneurons evoked by stimulating locally and delivered a train of high-frequency stimuli (20 pulses at $100 \mathrm{~Hz}$ ) via a second stimulating electrode positioned in stratum radiatum relatively far from the interneuron, with the aim of evoking ACh release from cholinergic axons. This evoked a small but significant and reversible depression of eIPSC amplitude ( $16 \pm 5 \%$ depression; $n=11$; $p<0.01$ ) (Fig. $8 A$ ). Interestingly, this depression developed over 3-4 min, an onset rate similar to that observed after either bath or local pressure application of agonists. The phenomenon was completely blocked by 100 nM MLA $(94.6 \pm 4.9 \%$ of baseline; $n=$ $7 ; p=0.31$ ), confirming that it was mediated by $\alpha 7 \mathrm{nAChRs}$ (Fig. $8 A, B)$.

We repeated the experiment with the conditioning electrode positioned in the alveus/stratum oriens, where the septohippocampal projection enters the hippocampus, in an attempt to
A

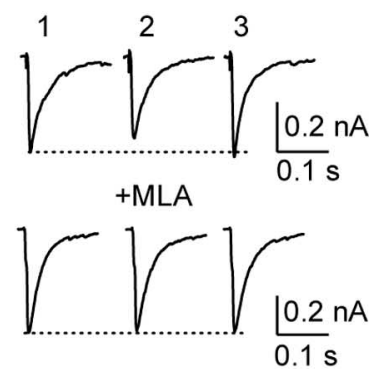

B

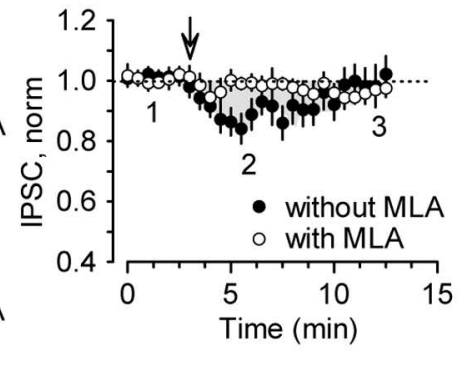

C
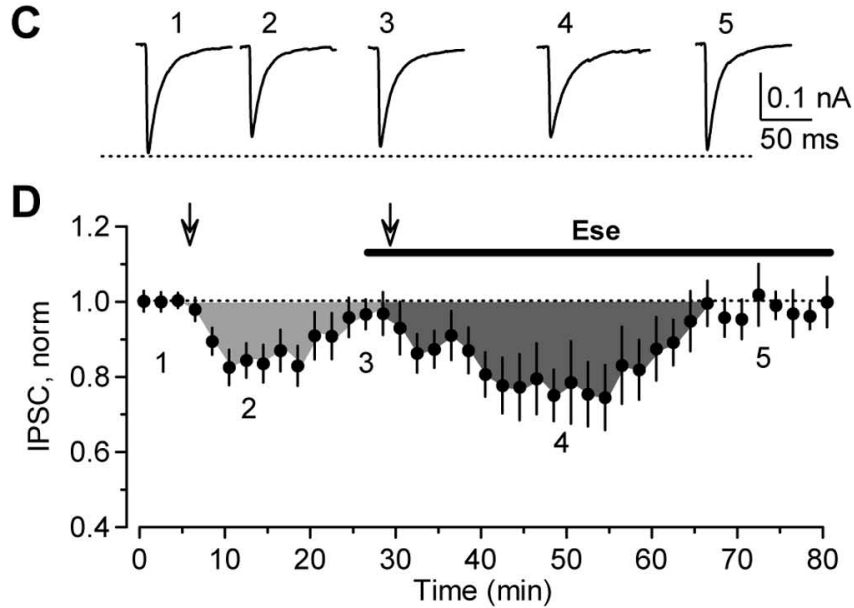

E

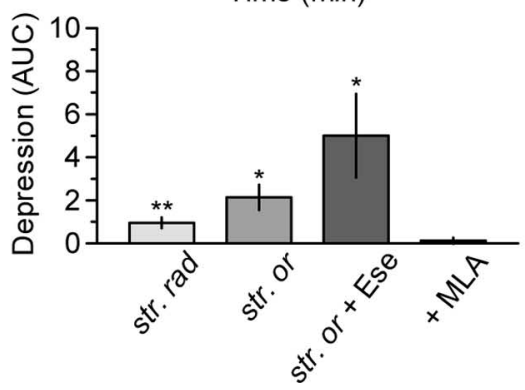

Figure 8. Endogenous ACh release evokes $\alpha 7$ nAChR-mediated depression of elPSC in CA1 interneurons. $\boldsymbol{A}$, Representative elPSCs obtained from one interneuron, before (1) and $3 \mathrm{~min}$ after (2) tetanic stimulation (arrow in $\boldsymbol{B} ; 20$ pulses at $100 \mathrm{~Hz}$ ) delivered via a second electrode placed in stratum radiatum and 10 min after conditioning (3). Top, Without MLA. Bottom, Results obtained during continued perfusion of $100 \mathrm{~nm}$ MLA. $\boldsymbol{B}$, Time course of heterosynaptic depression $(n=11)$ and blockade of the effect by $\operatorname{MLA}(n=7)$, showing the times at which the traces in $\boldsymbol{A}$ were obtained (1-3). C, Representative elPSCs obtained from one neuron, before (1) and after (2) tetanic stimulation (arrow in D) delivered to stratum oriens and after recovery (3). Tetanic stimulation (arrow) was delivered a second time in the presence of the anticholinesterase eserine (4). 5, Recovery. D, Time course of heterosynaptic depression before and after eserine application (Ese), showing times corresponding to the traces in $\boldsymbol{C}(n=9)$. $\boldsymbol{E}$, Summary of the extent of heterosynaptic depression expressed as the product of depression and duration (AUC) for the data shown in $\boldsymbol{B}$ and $\boldsymbol{D}$. str. rad, Stratum radiatum stimulation $(n=11)$; str. or, stratum oriens stimulation $(n=13)$; str. or + Ese, repeated in eserine $(n=9)$. MLA completely blocked heterosynaptic depression evoked by stratum oriens stimulation ( $\mathrm{MLA} ; n=4)$. ${ }^{*} p<0.05$; ${ }^{* *} p<0.01$. norm, Normalized.

recruit more cholinergic afferent fibers (Fig. $8 C, D$ ). We obtained an estimate of the extent of depression by taking the product of its amplitude and duration [area under the curve (AUC)]. This parameter was $2.14 \pm 0.60$ when the conditioning stimulation was delivered in the alveus/stratum oriens versus $0.96 \pm 0.25$ when delivered in stratum radiatum (Fig. $8 E$ ). To determine whether ACh hydrolysis limits the activation of nAChRs, we repeated the conditioning stimulation train (delivered to stratum oriens) in the presence of eserine $(5 \mu \mathrm{M})$. The depression was further en- 
hanced and prolonged in the presence of eserine (AUC, $5.01 \pm$ $1.90 ; n=9 ; p<0.05$ ) but completely blocked in the presence of MLA (Fig. $8 D, E$ ). This finding is consistent with the hypothesis that the endogenous agonist liberated by stimulus trains and acting on $\alpha 7 \mathrm{nAChRs}$ is indeed a substrate of cholinesterases, most likely ACh released from the cholinergic afferent projection from basal forebrain structures. Finally, we repeated the two-pathway experiment in a second species. This experiment gave a similar heterosynaptic depression ( $23 \pm 6 \%$; $n=4$; $p<0.001$ ) (supplemental Fig. $6 A, B, E$, available at www.jneurosci.org as supplemental material), which was partly reversible ( $92 \pm 4 \%$ of baseline; $p=0.12$ ). When $10 \mathrm{~mm}$ BAPTA was included in the intracellular solution, however, high-frequency stimulation delivered in stratum oriens failed to depress eIPSCs $(101 \pm 1 \% ; n=$ $6 ; p=0.37$ ) (supplemental Fig. 6C-E, available at www. jneurosci.org as supplemental material), further supporting a postsynaptic locus for the heterosynaptic modulation of GABAergic transmission.

\section{Discussion}

The main finding of this study is that $\alpha 7 \mathrm{nAChRs}$ modulate IPSCs by an action on $\mathrm{GABA}_{\mathrm{A}}$ receptors and that this effect is achieved not only by applying exogenous agonists but also by activating cholinergic axons in the hippocampus. This action of $\alpha 7 \mathrm{nAChRs}$ was seen in two species and in all stratum radiatum interneurons tested.

Despite their abundance in the hippocampus, the role of $\alpha 7$ nAChRs has been elusive. Most studies have focused either on direct depolarizing actions of ACh on interneurons or on the enhancement of neurotransmitter release, although postsynaptic modulatory effects have also been reported (Alkondon et al., 2000; Fisher and Dani, 2000). However, there are only very few reports that synaptically released ACh can achieve either of these effects. Indeed, only two actions of endogenous ACh on hippocampal nAChRs have been recorded with electrophysiological methods to date. First, three studies have reported that fast inward currents sensitive to $\alpha 7 \mathrm{nAChR}$ blockers can be elicited in interneurons (Alkondon et al., 1998; Frazier et al., 1998b; Hefft et al., 1999). Second, two other studies have reported a modulation of excitatory transmission that is consistent with a presynaptic switch in the mode of glutamate exocytosis (Maggi et al., 2003, 2004). By showing that nAChRs robustly downregulate $\mathrm{GABA}_{\mathrm{A}}$ receptors in all interneurons tested, the present study identifies a novel role in modulating inhibitory transmission among interneurons.

The complete postsynaptic cascade leading from nAChR activation to modulation of $\mathrm{GABA}_{\mathrm{A}}$ receptor-mediated currents remains to be elucidated. We found an obligatory role for an increase in $\left[\mathrm{Ca}^{2+}\right]_{\mathrm{i}}$, most simply explained by $\mathrm{Ca}^{2+}$ influx via $\alpha 7$ nAChRs, which have a high $\mathrm{Ca}^{2+}$ permeability (Bertrand et al., 1993; Seguela et al., 1993; Fucile, 2004). However, we cannot rule out a role for $\mathrm{Ca}^{2+}$ release from intracellular stores. $\mathrm{Ca}^{2+}$-evoked modulation of $\mathrm{GABA}_{\mathrm{A}}$ receptors has been described previously (Desaulles et al., 1991; Mulle et al., 1992; Stelzer and Shi, 1994; Wang and Stelzer, 1996; Akopian et al., 1998; Rossi et al., 2003), although this has not previously been shown to occur consequent to release of endogenous ACh. Several mechanisms have been proposed to underlie the dynamic regulation of $\mathrm{GABA}_{\mathrm{A}}$ receptors, mainly involving protein kinases and phosphorylases, leading to altered phosphorylation status of $\mathrm{GABA}_{\mathrm{A}}$ receptors and/or internalization (Kittler and Moss, 2003; Luscher and Keller, 2004).

We observed a profound, albeit incomplete, reduction in the effect of ACh on GABA currents when it was applied in the presence of either the broad-spectrum kinase blocker staurosporine or the more specific PKC blockers bisindolylmaleimide I and IP19-36. This is consistent with evidence that activators of PKC attenuate currents mediated by recombinant (Sigel and Baur, 1988 ) and native (Brandon et al., 2000) GABA receptors. However, the present results do not distinguish between instructive and permissive roles for PKC. Whether the effect of ACh is principally attributable to direct phosphorylation of $\beta$ subunits of GABA receptors (Browning et al., 1990) or to PKC-triggered internalization (Chapell et al., 1998) remains to be determined. If the main effect of nAChRs is to promote the internalization of receptors, the fact that the effect is slow and reversible suggests that this occurs against a background of constitutive cycling of receptors in and out of the synapse. Interestingly, the effect of $\alpha 7$ $\mathrm{nAChR}$ agonists on postsynaptic GABAergic signaling via activation of PKC is similar to that of exogenous activation of TrkB receptors (Tanaka et al., 1997; Brunig et al., 2001; Henneberger et al., 2002; Jovanovic et al., 2004), serotonin receptors (Feng et al., 2001), and muscarinic receptors (Brandon et al., 2002), suggesting substantial convergence of signaling.

Although staurosporine, bisindolylmaleimide I, and IP19-36 inhibited the $\alpha 7$ nAChR-mediated modulation of $\mathrm{GABA}_{\mathrm{A}}$ receptor-mediated currents to a similar extent, none of them fully blocked the effect, suggesting that another pathway may also contribute. Neither the tyrosine kinase blocker genistein nor the calcineurin blocker FK506 inhibited the action of ACh. A full characterization of the pathway leading from $\alpha 7 \mathrm{nAChRs}$ to $\mathrm{GABA}_{\mathrm{A}}$ receptors and of the role of $\mathrm{Ca}^{2+}$ stores and other GABA receptor-interacting proteins and adaptors (Luscher and Keller, 2004) is beyond the scope of this study.

The decrease in eIPSCs by electrical stimulation of cholinergic axons seen here was relatively small $(15-25 \%)$ relative to the effect of exogenous agonists (up to 50\% depression). However, the heterosynaptic depression of eIPSCs measured here underestimated the dynamic range available to this form of modulation because the stimulating electrode was positioned in the slice relatively far from the recorded cell to minimize the activation of monosynaptically coupled interneurons. Because many cholinergic afferents are likely to have been cut during tissue slicing, this probably compromised the ability to induce ACh release from all local varicosities.

It is, of course, surprising that $\alpha 7 \mathrm{nAChRs}$ should simultaneously evoke both a presynaptic increase in transmitter release and a postsynaptic downregulation of $\mathrm{GABA}_{\mathrm{A}}$ receptors, because the two effects would be expected to oppose one another. However, it is possible that the two are dissociable by parameters that we have not tested here, for instance in their temporal profiles or in their interaction with other influences on transmitter release and receptor activation.

The hippocampal GABAergic interneuron network is spontaneously active even when glutamatergic transmission is blocked and performs several functions, including rhythm setting (Cobb et al., 1995; Whittington et al., 1995). GABAergic transmission among interneurons is highly sensitive to several neurotransmitters acting via presynaptic and axonal receptors (Semyanov and Kullmann, 2000, 2001; Cossart et al., 2001), suggesting that modulation of this form of communication is important for the normal function of the hippocampus. Several of these modulatory phenomena specifically affect GABAergic transmission to interneurons, as opposed to pyramidal neurons (for review, see Semyanov, 2003). The modulation of postsynaptic $\mathrm{GABA}_{\mathrm{A}}$ receptors revealed in the present study also obeys this principle and is con- 
sistent with the higher density of $\alpha 7 \mathrm{nAChRs}$ in interneurons than in pyramidal cells. Because most cholinergic axons arise from extrinsic structures rather than intrinsic ACh-releasing neurons (Frotscher et al., 1986) the phenomenon reported here provides a possible novel mechanism for an afferent projection to the hippocampus to affect synaptic transmission among interneurons. The evidence implicating $\alpha 7 \mathrm{nAChRs}$ in cognition and schizophrenia further argues that modulation of $\mathrm{GABA}_{\mathrm{A}}$ receptors by ACh release plays an important role in the informationprocessing functions of the hippocampus.

During revision of this paper, Zhang and Berg (2007) reported findings that are broadly in agreement with our study.

\section{References}

Akopian A, Gabriel R, Witkovsky P (1998) Calcium released from intracellular stores inhibits GABAA-mediated currents in ganglion cells of the turtle retina. J Neurophysiol 80:1105-1115.

Alkondon M, Pereira EF, Barbosa CT, Albuquerque EX (1997a) Neuronal nicotinic acetylcholine receptor activation modulates gammaaminobutyric acid release from CA1 neurons of rat hippocampal slices. J Pharmacol Exp Ther 283:1396-1411.

Alkondon M, Pereira EF, Cortes WS, Maelicke A, Albuquerque EX (1997b) Choline is a selective agonist of alpha7 nicotinic acetylcholine receptors in the rat brain neurons. Eur J Neurosci 9:2734-2742.

Alkondon M, Pereira EF, Albuquerque EX (1998) Alpha-bungarotoxinand methyllycaconitine-sensitive nicotinic receptors mediate fast synaptic transmission in interneurons of rat hippocampal slices. Brain Res 810:257-263.

Alkondon M, Braga MF, Pereira EF, Maelicke A, Albuquerque EX (2000) Alpha7 nicotinic acetylcholine receptors and modulation of gabaergic synaptic transmission in the hippocampus. Eur J Pharmacol 393:59-67.

Bertrand D, Galzi JL, Devillers-Thiery A, Bertrand S, Changeux JP (1993) Mutations at two distinct sites within the channel domain M2 alter calcium permeability of neuronal alpha 7 nicotinic receptor. Proc Natl Acad Sci USA 90:6971-6975.

Brandon NJ, Delmas P, Kittler JT, McDonald BJ, Sieghart W, Brown DA, Smart TG, Moss SJ (2000) GABAA receptor phosphorylation and functional modulation in cortical neurons by a protein kinase C-dependent pathway. J Biol Chem 275:38856-38862.

Brandon NJ, Jovanovic JN, Smart TG, Moss SJ (2002) Receptor for activated $\mathrm{C}$ kinase-1 facilitates protein kinase $\mathrm{C}$-dependent phosphorylation and functional modulation of $\mathrm{GABA}_{\mathrm{A}}$ receptors with the activation of G-protein-coupled receptors. J Neurosci 22:6353-6361.

Browning MD, Bureau M, Dudek EM, Olsen RW (1990) Protein kinase C and cAMP-dependent protein kinase phosphorylate the beta subunit of the purified gamma-aminobutyric acid A receptor. Proc Natl Acad Sci USA 87:1315-1318.

Brunig I, Penschuck S, Berninger B, Benson J, Fritschy JM (2001) BDNF reduces miniature inhibitory postsynaptic currents by rapid downregulation of $\operatorname{GABA}(\mathrm{A})$ receptor surface expression. Eur J Neurosci 13:1320-1328.

Buhler AV, Dunwiddie TV (2002) alpha7 nicotinic acetylcholine receptors on GABAergic interneurons evoke dendritic and somatic inhibition of hippocampal neurons. J Neurophysiol 87:548-557.

Chapell R, Bueno OF, Alvarez-Hernandez X, Robinson LC, Leidenheimer NJ (1998) Activation of protein kinase $\mathrm{C}$ induces gamma-aminobutyric acid type A receptor internalization in Xenopus oocytes. J Biol Chem 273:32595-32601.

Cobb SR, Buhl EH, Halasy K, Paulsen O, Somogyi P (1995) Synchronization of neuronal activity in hippocampus by individual GABAergic interneurons. Nature 378:75-78.

Cossart R, Tyzio R, Dinocourt C, Esclapez M, Hirsch JC, Ben-Ari Y, Bernard C (2001) Presynaptic kainate receptors that enhance the release of GABA on CA1 hippocampal interneurons. Neuron 29:497-508.

Couturier S, Bertrand D, Matter JM, Hernandez MC, Bertrand S, Millar N, Valera S, Barkas T, Ballivet M (1990) A neuronal nicotinic acetylcholine receptor subunit (alpha 7) is developmentally regulated and forms a homo-oligomeric channel blocked by alpha-BTX. Neuron 5:847-856.

Cummings JL (2004) Alzheimer's disease. N Engl J Med 351:56-67.

Davies P, Maloney AJ (1976) Selective loss of central cholinergic neurons in Alzheimer's disease. Lancet 2:1403.
Desaulles E, Boux O, Feltz P (1991) Caffeine-induced Ca2 + release inhibits GABAA responsiveness in rat identified native primary afferents. Eur J Pharmacol 203:137-140.

Descarries L, Mechawar N, Aznavour N, Watkins KC (2004) Structural determinants of the roles of acetylcholine in cerebral cortex. Prog Brain Res 145:45-58.

Fabian-Fine R, Skehel P, Errington ML, Davies HA, Sher E, Stewart MG, Fine A (2001) Ultrastructural distribution of the $\alpha 7$ nicotinic acetylcholine receptor subunit in rat hippocampus. J Neurosci 21:7993-8003.

Feng J, Cai X, Zhao J, Yan Z (2001) Serotonin receptors modulate GABA receptor channels through activation of anchored protein kinase $\mathrm{C}$ in prefrontal cortical neurons. J Neurosci 21:6502-6511.

Fisher JL, Dani JA (2000) Nicotinic receptors on hippocampal cultures can increase synaptic glutamate currents while decreasing the NMDAreceptor component. Neuropharmacology 39:2756-2769.

Frazier CJ, Rollins YD, Breese CR, Leonard S, Freedman R, Dunwiddie TV (1998a) Acetylcholine activates an $\alpha$-bungarotoxin-sensitive nicotinic current in rat hippocampal interneurons, but not pyramidal cells. J Neurosci 18:1187-1195.

Frazier CJ, Buhler AV, Weiner JL, Dunwiddie TV (1998b) Synaptic potentials mediated via $\alpha$-bungarotoxin-sensitive nicotinic acetylcholine receptors in rat hippocampal interneurons. J Neurosci 18:8228-8235.

Freedman R, Wetmore C, Stromberg I, Leonard S, Olson L (1993) $\alpha$-Bungarotoxin binding to hippocampal interneurons: immunocytochemical characterization and effects on growth factor expression. J Neurosci 13:1965-1975.

Freedman R, Hall M, Adler LE, Leonard S (1995) Evidence in postmortem brain tissue for decreased numbers of hippocampal nicotinic receptors in schizophrenia. Biol Psychiatry 38:22-33.

Freedman R, Coon H, Myles-Worsley M, Orr-Urtreger A, Olincy A, Davis A, Polymeropoulos M, Holik J, Hopkins J, Hoff M, Rosenthal J, Waldo MC, Reimherr F, Wender P, Yaw J, Young DA, Breese CR, Adams C, Patterson $D$, Adler LE, et al. (1997) Linkage of a neurophysiological deficit in schizophrenia to a chromosome 15 locus. Proc Natl Acad Sci USA 94:587-592.

Frerking M, Petersen CC, Nicoll RA (1999) Mechanisms underlying kainate receptor-mediated disinhibition in the hippocampus. Proc Natl Acad Sci USA 96:12917-12922.

Frotscher M, Schlander M, Leranth C (1986) Cholinergic neurons in the hippocampus. A combined light- and electron-microscopic immunocytochemical study in the rat. Cell Tissue Res 246:293-301.

Fucile S (2004) Ca2 + permeability of nicotinic acetylcholine receptors. Cell Calcium 35:1-8

Gray R, Rajan AS, Radcliffe KA, Yakehiro M, Dani JA (1996) Hippocampal synaptic transmission enhanced by low concentrations of nicotine. Nature 383:713-716.

Hefft S, Hulo S, Bertrand D, Muller D (1999) Synaptic transmission at nicotinic acetylcholine receptors in rat hippocampal organotypic cultures and slices. J Physiol (Lond) 515:769-776.

Henneberger C, Juttner R, Rothe T, Grantyn R (2002) Postsynaptic action of BDNF on GABAergic synaptic transmission in the superficial layers of the mouse superior colliculus. J Neurophysiol 88:595-603.

Herber DL, Severance EG, Cuevas J, Morgan D, Gordon MN (2004) Biochemical and histochemical evidence of nonspecific binding of $\alpha 7 \mathrm{nAChR}$ antibodies to mouse brain tissue. J Histochem Cytochem 52:1367-1376.

Hogan DB, Goldlist B, Naglie G, Patterson C (2004) Comparison studies of cholinesterase inhibitors for Alzheimer's disease. Lancet Neurol 3:622-626.

Hogg RC, Raggenbass M, Bertrand D (2003) Nicotinic acetylcholine receptors: from structure to brain function. Rev Physiol Biochem Pharmacol $147: 1-46$

Horn R, Marty A (1988) Muscarinic activation of ionic currents measured by a new whole-cell recording method. J Gen Physiol 92:145-159.

Ji D, Dani JA (2000) Inhibition and disinhibition of pyramidal neurons by activation of nicotinic receptors on hippocampal interneurons. J Neurophysiol 83:2682-2690.

Jones S, Yakel JL (1997) Functional nicotinic ACh receptors on interneurones in the rat hippocampus. J Physiol 504:603-610.

Jovanovic JN, Thomas P, Kittler JT, Smart TG, Moss SJ (2004) Brainderived neurotrophic factor modulates fast synaptic inhibition by regulating $\mathrm{GABA}_{\mathrm{A}}$ receptor phosphorylation, activity, and cell-surface stability. J Neurosci 24:522-530. 
Kawai H, Zago W, Berg DK (2002) Nicotinic $\alpha 7$ receptor clusters on hippocampal GABAergic neurons: regulation by synaptic activity and neurotrophins. J Neurosci 22:7903-7912.

Khiroug L, Giniatullin R, Klein RC, Fayuk D, Yakel JL (2003) Functional mapping and $\mathrm{Ca}^{2+}$ regulation of nicotinic acetylcholine receptor channels in rat hippocampal CA1 neurons. J Neurosci 23:9024-9031.

Kittler JT, Moss SJ (2003) Modulation of GABAA receptor activity by phosphorylation and receptor trafficking: implications for the efficacy of synaptic inhibition. Curr Opin Neurobiol 13:341-347.

Kullmann PH, Wheeler DW, Beacom J, Horn JP (2004) Implementation of a fast 16-bit dynamic clamp using LabVIEW-RT. J Neurophysiol 91:542-554.

Lee MG, Chrobak JJ, Sik A, Wiley RG, Buzsaki G (1994) Hippocampal theta activity following selective lesion of the septal cholinergic system. Neuroscience 62:1033-1047.

Lu YM, Mansuy IM, Kandel ER, Roder J (2000) Calcineurin-mediated LTD of GABAergic inhibition underlies the increased excitability of CA1 neurons associated with LTP. Neuron 26:197-205.

Luscher B, Keller CA (2004) Regulation of GABAA receptor trafficking, channel activity, and functional plasticity of inhibitory synapses. Pharmacol Ther 102:195-221.

MacDermott AB, Role LW, Siegelbaum SA (1999) Presynaptic ionotropic receptors and the control of transmitter release. Annu Rev Neurosci 22:443-485.

Maggi L, Le Magueresse C, Changeux JP, Cherubini E (2003) Nicotine activates immature "silent" connections in the developing hippocampus. Proc Natl Acad Sci USA 100:2059-2064.

Maggi L, Sola E, Minneci F, Le Magueresse C, Changeux JP, Cherubini E (2004) Persistent decrease in synaptic efficacy induced by nicotine at Schaffer collateral-CA1 synapses in the immature rat hippocampus. J Physiol (Lond) 559:863-874.

Manabe T, Wyllie DJ, Perkel DJ, Nicoll RA (1993) Modulation of synaptic transmission and long-term potentiation: effects on paired pulse facilitation and EPSC variance in the CA1 region of the hippocampus. J Neurophysiol 70:1451-1459.

McGehee DS, Heath MJ, Gelber S, Devay P, Role LW (1995) Nicotine enhancement of fast excitatory synaptic transmission in CNS by presynaptic receptors. Science 269:1692-1696.

McQuiston AR, Madison DV (1999) Nicotinic receptor activation excites distinct subtypes of interneurons in the rat hippocampus. J Neurosci 19:2887-2896.

Mesulam M (2004a) The cholinergic lesion of Alzheimer's disease: pivotal factor or side show? Learn Mem 11:43-49.

Mesulam MM (2004b) The cholinergic innervation of the human cerebral cortex. Prog Brain Res 145:67-78.

Mogg AJ, Whiteaker P, McIntosh JM, Marks M, Collins AC, Wonnacott S (2002) Methyllycaconitine is a potent antagonist of alpha-conotoxinMII-sensitive presynaptic nicotinic acetylcholine receptors in rat striatum. J Pharmacol Exp Ther 302:197-204.

Mulle C, Choquet D, Korn H, Changeux JP (1992) Calcium influx through nicotinic receptor in rat central neurons: its relevance to cellular regulation. Neuron 8:135-143.

Newhouse PA, Potter A, Singh A (2004) Effects of nicotinic stimulation on cognitive performance. Curr Opin Pharmacol 4:36-46.

Papke RL, Porter Papke JK (2002) Comparative pharmacology of rat and human alpha7 nAChR conducted with net charge analysis. Br J Pharmacol 137:49-61.
Papke RL, Meyer E, Nutter T, Uteshev VV (2000) Alpha7 receptor-selective agonists and modes of alpha7 receptor activation. Eur J Pharmacol 393:179-195.

Ripoll N, Bronnec M, Bourin M (2004) Nicotinic receptors and schizophrenia. Curr Med Res Opin 20:1057-1074.

Rossi DJ, Hamann M, Attwell D (2003) Multiple modes of GABAergic inhibition of rat cerebellar granule cells. J Physiol (Lond) 548:97-110.

Seguela P, Wadiche J, Dineley-Miller K, Dani JA, Patrick JW (1993) Molecular cloning, functional properties, and distribution of rat brain $\alpha 7$ : a nicotinic cation channel highly permeable to calcium. J Neurosci 13:596-604.

Semyanov A (2003) Cell type specificity of GABA(A) receptor mediated signaling in the hippocampus. Curr Drug Targets CNS Neurol Disord 2:240-247.

Semyanov A, Kullmann DM (2000) Modulation of GABAergic signaling among interneurons by metabotropic glutamate receptors. Neuron 25:663-672.

Semyanov A, Kullmann DM (2001) Kainate receptor-dependent axonal depolarization and action potential initiation in interneurons. Nat Neurosci 4:718-723.

Sigel E, Baur R (1988) Activation of protein kinase C differentially modulates neuronal $\mathrm{Na}+, \mathrm{Ca} 2+$, and gamma-aminobutyrate type A channels. Proc Natl Acad Sci USA 85:6192-6196.

Smith MK, Colbran RJ, Soderling TR (1990) Specificities of autoinhibitory domain peptides for four protein kinases. Implications for intact cell studies of protein kinase function. J Biol Chem 265:1837-1840.

Stelzer A, Shi H (1994) Impairment of GABAA receptor function by $\mathrm{N}$-methyl-D-aspartate-mediated calcium influx in isolated CA1 pyramidal cells. Neuroscience 62:813-828.

Tanaka T, Saito H, Matsuki N (1997) Inhibition of $\mathrm{GABA}_{\mathrm{A}}$ synaptic responses by brain-derived neurotrophic factor (BDNF) in rat hippocampus. J Neurosci 17:2959-2966.

Umbriaco D, Garcia S, Beaulieu C, Descarries L (1995) Relational features of acetylcholine, noradrenaline, serotonin and GABA axon terminals in the stratum radiatum of adult rat hippocampus (CA1). Hippocampus 5:605-620.

Vizi ES, Rozsa B, Mayer A, Kiss JP, Zelles T, Lendvai B (2004) Further evidence for the functional role of nonsynaptic nicotinic acetylcholine receptors. Eur J Pharmacol 500:499-508.

Wang J, Liu S, Haditsch U, Tu W, Cochrane K, Ahmadian G, Tran L, Paw J, Wang Y, Mansuy I, Salter MM, Lu YM (2003) Interaction of calcineurin and type-A GABA receptor $\gamma 2$ subunits produces long-term depression at CA1 inhibitory synapses. J Neurosci 23:826-836.

Wang JH, Stelzer A (1996) Shared calcium signaling pathways in the induction of long-term potentiation and synaptic disinhibition in CA1 pyramidal cell dendrites. J Neurophysiol 75:1687-1702.

Whittington MA, Traub RD, Jefferys JG (1995) Synchronized oscillations in interneuron networks driven by metabotropic glutamate receptor activation [see comments]. Nature 373:612-615.

Zago WM, Massey KA, Berg DK (2006) Nicotinic activity stabilizes convergence of nicotinic and GABAergic synapses on filopodia of hippocampal interneurons. Mol Cell Neurosci 31:549-559.

Zhang J, Berg DK (2007) Reversible inhibition of GABAA receptors by $\alpha 7$ containing nicotinic receptors on the vertebrate postsynaptic neurons. J Physiol (Lond) 579:753-763. 